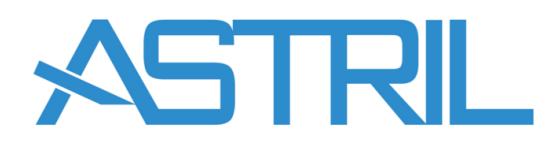

Associazione Studi e Ricerche Interdisciplinari sul Lavoro

\author{
Working Paper $n^{\circ}$ 43/2019 \\ (number 1 Jean Monnet series)
}

\title{
JOB MOBILITY AND HETEROGENEOUS RETURNS TO APPRENTICENSHIP TRAINING IN ITALY
}

Giorgio d'Agostino, Michele Raitano, Margherita Scarlato

Anno 2019

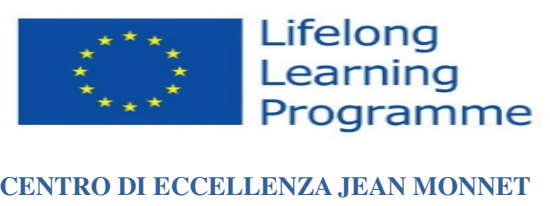

ISSN 2280 - 6229 -Working Papers - on line

ASTRIL (Associazione Studi e Ricerche Interdisciplinari sul Lavoro 
I Working Papers di ASTRIL svolgono la funzione di divulgare tempestivamente, in forma definitiva o provvisoria, i risultati di ricerche scientifiche originali. La loro pubblicazione è soggetta all'approvazione del Comitato Scientifico.

esemplare fuori commercio

ai sensi della legge 14 aprile 2004 n.106

Per ciascuna pubblicazione vengono soddisfatti gli obblighi previsti dall'art. I del D.L.L. 31.8.1945, n. 660 e successive modifiche.

\section{Comitato Scientifico}

Sebastiano Fadda

Franco Liso

Arturo Maresca

Paolo Piacentini

\section{REDAZIONE:}

ASTRIL

Università degli Studi Roma Tre

Via Silvio D'Amico, 77 - 00145 Roma

Tel. 0039-06-57335751; 06-57335723

E-mail: astril@uniroma3.it

http://host.uniroma3.it/associazioni/astril 


\title{
Job mobility and heterogeneous returns to apprenticeship training in Italy
}

\author{
Giorgio d'Agostino ${ }^{1}$ \\ Roma Tre University \\ Michele Raitano $^{2}$ \\ Sapienza University of Rome \\ Margherita Scarlato ${ }^{3}$ \\ Roma Tre University
}

\begin{abstract}
Apprenticeship may provide an important opportunity to improve human capital and future earnings of young people, especially those with low levels of education. Based on new administrative data, we provide the first empirical evidence of the effect on wages and employability of the mobility across firms and economic sectors of apprentices after graduation in Italy. We use an instrumental variable approach to account for endogenous selection that is based on observed and unobserved characteristics when estimating the causal effects of mobility. Our main finding is that job switchers outside the economic sector of the training firm faced a considerable gap in wages and weeks worked in comparison to stayers in the training firm, indicating a loss of firm-specific human capital. In addition, the new apprenticeship introduced by the Biagi reform, which lessened the stringency of the norms on the training content delivered by firms, resulted in further reductions of the transferability of skills for trainees relative to the previous regime. Overall, the apprenticeship contract in Italy generated earning gaps according to the workers' mobility after graduation, thus increasing inequality among similar employees.
\end{abstract}

Keywords: Apprenticeship training, Job mobility, Wages.

JEL classification: J24, J62, J31, J38.

Acknowledgement: The authors wish to thank Fabrizio Patriarca for his helpful and insightful suggestions. Michele Raitano thanks Fondazione Giacomo Brodolini for the use of the dataset AD-SILC. The usual disclaimers apply.

\section{Introduction}

Over the last decade, there has been a considerable increase in the number of young people unemployed in several European countries. According to OECD data (OECD, 2018), youth (15-24 years old) unemployment rates in 2017 were close to 35\% in Italy, 39\% in Spain, and 44\% in Greece. Many young people have responded to sluggish labour market prospects by withdrawing from education and employment, as indicated by the share of youth (aged 15 to 29) not in education, employment or training (NEET), which in 2017 reached $20 \%$ in Spain and up to $23 \%$ in Greece and $25 \%$ in Italy (OECD, 2018).

Against this background, apprenticeship has received much attention from policy makers as a means to improve the opportunities of youth and address skill imbalances in Europe by establishing a better match of

\footnotetext{
${ }^{1}$ Department of Economics, Via Silvio D'Amico 77, Rome (Italy). Email: giorgio.dagostino@uniroma3.it.

${ }^{2}$ Department of Economics and Law, Via Del Castro Laurenziano 9, Rome (Italy). Email: michele.raitano@uniroma1.it.

${ }^{3}$ Department of Economics, Via Silvio D'Amico 77, Rome (Italy). Email: margherita.scarlato@uniroma3.it.
} 
workers' skills to firm needs (European Commission, 2017; Pastore, 2017; Ryan, 2001). A growing body of research has investigated the effectiveness of apprenticeship schemes in European countries as well (Bassanini et al., 2006, Eichhorst et al., 2015). Specifically, a large corpus of literature explores the individual effect of apprenticeship on the accumulation and transferability of skills by considering the wage profiles of graduates, which are expected to reflect higher productivity from training investments, and addressing non-random selection into apprenticeship and job mobility (Fersterer et al., 2008; Fitzenberger et al., 2015, Göggel and Zwick, 2012, McIntosh and Morris, 2018).

The existing literature has typically examined the dual apprenticeship system in Germany, which combines state-provided school-based education with firm-provided on-the-job training as a role model (Fitzenberger et al., 2015, Korpi and Mertens, 2003, Mohrenweiser and Zwick, 2009, Rendall and Weiss, 2016), and has investigated the optimal mix of general and specific skills delivered by alternative training schemes in terms of the productivity enhancement of workers and returns to human capital that workers are able to capture (Acemoglu and Pischke, 1998, 1999a b; Felli and Harris, 1996, Malcomson et al., 2003, Wasmer, 2006). It has also been argued that regulation enforcing the commitment of firms to training, which is not verifiable when it takes place within firms, is a key component of successful apprenticeship programmes. Indeed, since apprenticeship contracts are directly or indirectly subsidised in most cases, enforcement devices reduce the risk that apprentices are abused as cheap labour or that firms provide training that is too specific (Dustmann and Schönberg, 2012). In a more general perspective, the structure of incentives shaping the commitment to high-quality training is the crucial factor to ensure significant returns to graduates who stay in the training firm and to job switchers (Acemoglu and Pischke, 1999b; Leuven, 2005, Ryan et al., 2013). According to these different strands of studies, whether or not apprenticeship has a payoff for young workers depends on the design of the scheme, and it is ultimately an empirical question.

This paper adds to the literature on apprenticeship returns by providing a contribution that is novel in several respects. First, we focus on the Italian case, whose policy relevance is great, given that very few studies have analysed the effects of apprenticeship in this context. Picchio and Staffolani (2013) use Italian survey data and investigate if apprenticeship is an effective pathway into permanent jobs, compared to other forms of temporary work. They find that apprentices are more likely to obtain a permanent job, especially within the same firm rather than outside, once the apprenticeship period expires. However, this analysis cannot disentangle the contribution of the specific and general human capital accumulation from the contribution of the screening hypothesis in determining the empirical findings. Similarly, Bosco and Valeriani (2018) use a large observational dataset at the employee level and find a weak stepping-stone effect on permanent jobs for apprenticeship, although again, self-selection issues are at work. Albanese et al. (2017), Cappellari et al. (2012) and d'Agostino et al. (2018), using administrative data, minimise the problems of selection and omitted variables bias by estimating the causal effect of changing the apprenticeship contract features with the so-called Biagi Law on the transition of the apprentices to open-ended contracts and show a positive impact on job reallocation. Albanese et al. (2017) also find long-term effects of the reform on apprentices' wages. This result is consistent with a pattern of higher job stability and is compatible with the hypothesis of increased human capital accumulation due to the training provisions set by the reform.

This literature does not provide an overall analysis of the impact of apprenticeship on the accumulation of human capital and the prospective returns of the training investment to former trainees, nor does it directly address the issue of the selection bias related to idiosyncratic characteristics of young people involved in training activities, with good-quality workers obtaining better chances after graduation. We contribute to filling this gap by following the approach proposed by Fitzenberger et al. (2015). In detail, we infer the impact of training on apprentices' skills and productivity by estimating the causal effect on wages of job mobility among prime-aged graduates from apprenticeship in Italy, both within the economic sector of the training firm and across different economic sectors. We adopt an instrumental variable (IV) approach, exploiting time and regional variation of labour market characteristics to control for selection bias and confounding factors. Analysing the effect on wages of mobility after graduation allows us to speculate on several issues. First, when apprenticeship provides firm-specific human capital, we expect that mobility of graduates across firms involves a loss of the human capital component that is not transferable to the new job and that this effect translates into in a wage loss. Second, we suppose that the wage gap between stayers (i.e., graduates who do not switch their job) and job switchers is larger when the apprentice shifts to a job in a different economic sector. Last, when apprenticeship also provides general human capital, one would expect that mobility across firms and sectors involves just a small, presumably temporary, wage loss. 
The second novelty of the paper is that we extend the approach of Fitzenberger et al. (2015) and analyse the pattern of three outcome variables, viz. annual earnings, annual weeks worked and weekly wages. As our analysis focuses on apprentices transitioning to the status of dependent employees with a permanent contract in the private sector (controlling for those working on a part-time basis), the outcome variable, 'weekly wage', is a proxy for the hourly wage, which reflects skills and productivity. By examining the behaviour of earnings, disentangling wage effects that are related to the 'pure' training impact from effects related to variations in work utilisation after placement, we can draw deeper implications under two perspectives, viz. the efficiency of the training scheme in providing transferable human capital and the equity of the distribution of the gains from training across firms and former apprentices. For this scope, we use new administrative data, recently made available, that allow us to observe workers who completed apprenticeship training during the period 1997-2012. We disentangle transitory effects and persistent effects by considering individuals in employment at least from one year after graduation from apprenticeship and, then, by restricting the sample to those individuals that we observe in employment at least for the first three years and the first five years after graduation from apprenticeship.

Finally, building on Albanese et al. (2017), Cappellari et al. (2012) and d'Agostino et al. (2018), we provide further evidence on the effects of the reform of the apprenticeship regime implemented in Italy by the Biagi Law, which lessened the stringency of the norms on the training content delivered by firms within the overhaul of the labour market towards the reduction of employment protection legislation (EPL) 'at the margin'. Hence, we contribute to the literature on the differential impact of alternative training schemes of apprenticeship on the accumulation and transferability of the skills of young workers. This evidence also sheds new light on the consequences of the progressive deregulation implemented in the Italian labour market on training and within workers' earnings inequality

Using those who remain working in the training firm (henceforth, the stayers) as the comparison group, we find that job switchers to a different economic sector faced a considerable gap in both wages and intensity of work supplied and fared worse than job switchers who remained in the same sector of the training firm, indicating a loss of firm-specific human capital. In addition, our findings suggest that the arrangements of the training scheme set by the Biagi reform have significantly weakened the transferability of the skills of graduates from apprenticeship. Last, when allowing for heterogeneity by firm size, a stark contrast emerges in the results for small and large firms. The policy implications of the empirical analysis are twofold and regard both the efficiency and the equity dimensions. On the one hand, the apprenticeship contract in Italy, overall, has not been effective in generating transferable returns to training for young workers. On the other hand, as apprenticeship has produced wage gaps and differential work intensity among trained workers with the same endowment of human capital, the spread of this contract over the last twenty years might have ultimately contributed to increased inequalities in the labour earnings and working conditions of similar workers.

The remainder of the paper is organised as follows. Section 2 documents some peculiar features of the youth labour market in Italy. Section 3 describes the dataset, the sample selection and the main variables. Section 4 discusses the identification and estimation strategy. Section 5 presents and discusses the empirical results and provides some robustness checks. Last, Section 6 states the main conclusions.

\section{A first look at the youth labour market}

This section documents the institutional background and some key pieces of evidence to motivate our subsequent empirical analysis. The starting point is that, over the last 30 years, the youth (15-29 years old) unemployment rate has been a persistent challenge in the Italian labour market. Figure 1 (panel a) sketches a picture of the unemployment rates by age groups, showing that the unemployment of young people was more than two times higher than adult unemployment for the analysed time span 5 . Youth employment outcomes were considerably aggravated in the wake of the global crisis, which disproportionately affected the weakest segments of the labour market (Adda and Triggari, 2016). Figure1 (panel b) also illustrates that less-educated people were faring worse than people attaining a higher level of education, and the difference in

\footnotetext{
${ }^{4}$ See Bratti et al. (2018) for a detailed discussion of the literature on the impact of EPL on firm-provided training.

${ }^{5}$ We restrict the analysed time period to the range of 1998-2011 due to the availability of comparable data for all the contractual typologies in our dataset.
} 
Figure 1: Unemployment rates by age and education level

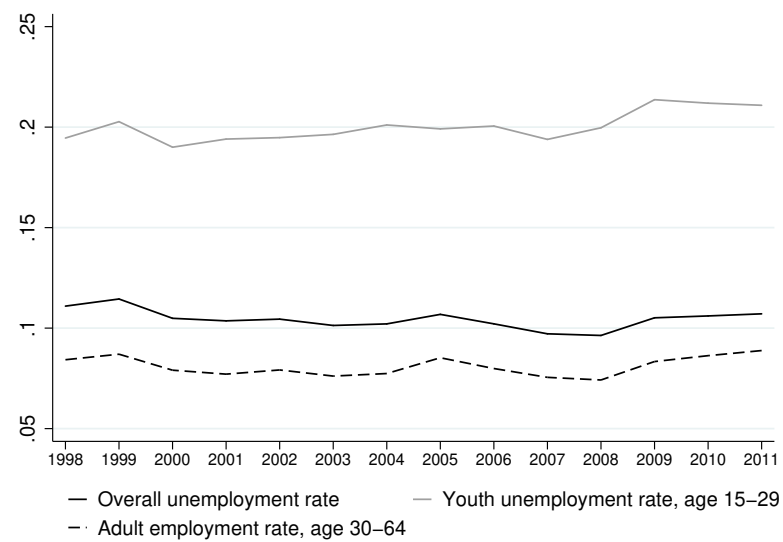

(a) Age

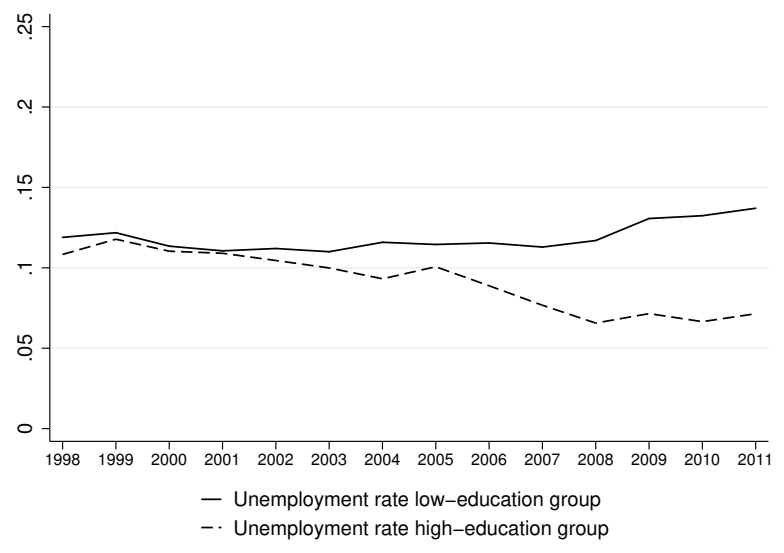

(b) Education level

Notes: The low-education group includes workers with primary and secondary education degrees, whereas the high-education group includes workers with a tertiary education degree. The shares of unemployed in the high- and low-education groups are not constant over time: the first share ranges in the interval 11-16\%, and the second one ranges in the interval 34-44\%. Source: AD-SILC longitudinal dataset.

the rates of unemployment of these two groups increased steadily over tim ${ }^{6}$ As apparent from this evidence, young people and people with low skills constitute a large part of the structural unemployment problem in Italy (Bertola and Garibaldi, 2006, Choudhry et al., 2012).

Policy measures that target the young unemployed were introduced in Italy starting from the late 1990s through an incremental process based on the reduction of EPL for new hires (Cappellari et al., 2012. d'Agostino et al. 2018/7. The Pacchetto Treu (Law No. 196/1997) gradually expanded the scope for atypical contracts, and the Biagi Law (Law No. 30/2003) systematically increased the flexibility of the labour market by introducing new atypical contracts and by relaxing the restrictions on their use.

Within temporary contracts that are involved in the reform process, the two most popular types are fixed-term and apprenticeship. The fixed-term contract allows firms to hire workers for a period of a definite duration, but it entails the same amount of social security contributions as an open-ended contract and no cost saving for the firm (apart from firing costs). In 2001, Law No. 368, based on an EU directive, relieved employers of being obliged to define specific reasons for using fixed-term contracts and eliminated mandatory limits to their renewal. Later, Law No. 247/2007 introduced a limit of three years in the maximum duration of fixed-term contracts stipulated with the same employer. The apprenticeship contract, instead, is one of the so-called causa mista contracts, which requires the firm to provide the worker with some training while involving lower social security contributions for the employer to compensate for training costs. Note that the rationale of both types of temporary contracts is to buffer demand fluctuations, screen workers and favour the accumulation of work experience in the transition of young people from school to the labour market, narrowing the experience gap with adults (Vidal and Tigges, 2009). However, the apprenticeship should also improve the other components of human capital, i.e., general and job-specific skills. In this respect, the apprenticeship contract is the appropriate measure to address structural issues, such as integrating lesseducated young people into good quality employment and reducing the mismatch between the knowledge acquired through formal education and the skills required by the labour market.

The regulatory framework for apprenticeship has undergone significant transformations in an attempt to enhance the proper scope of this contract, which was otherwise frequently used by Italian employers as a

\footnotetext{
${ }^{6}$ Data from the Labour Force Survey, provided by the Italian Institute of Statistics (ISTAT), show that in 2015, the lesseducated youth unemployment rate reached a peak of approximately $40 \%$ and recovered slowly over the following years.

${ }^{7}$ See d'Agostino et al. (2018) for a detailed discussion on the evolution of these policy measures.
} 
Figure 2: Youth (15-29 years old) employment shares of new entrants by contract type and education level

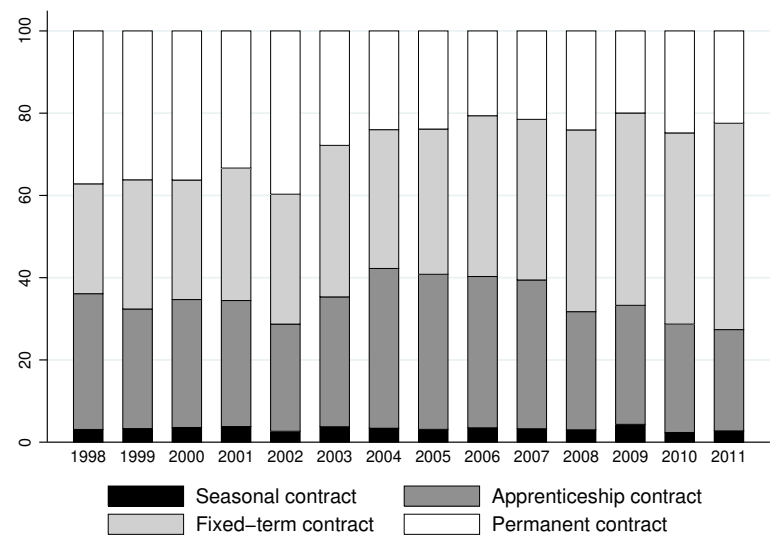

(a) Overall employment shares

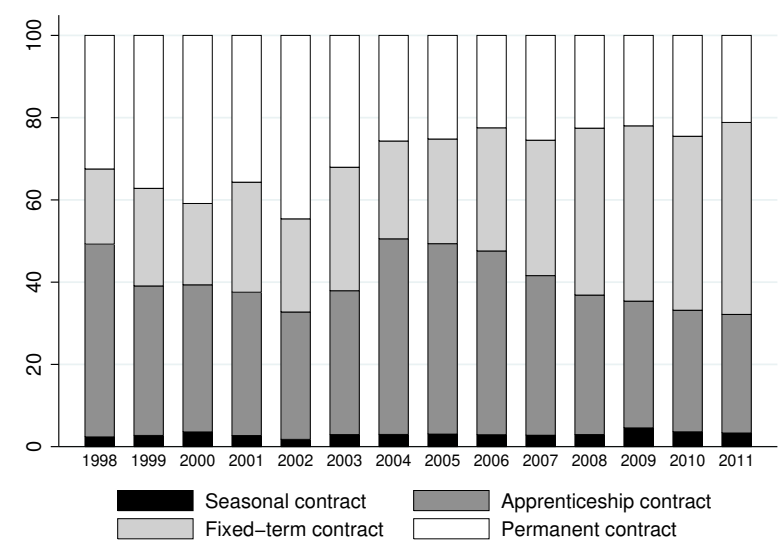

(b) Employment shares, low-education group

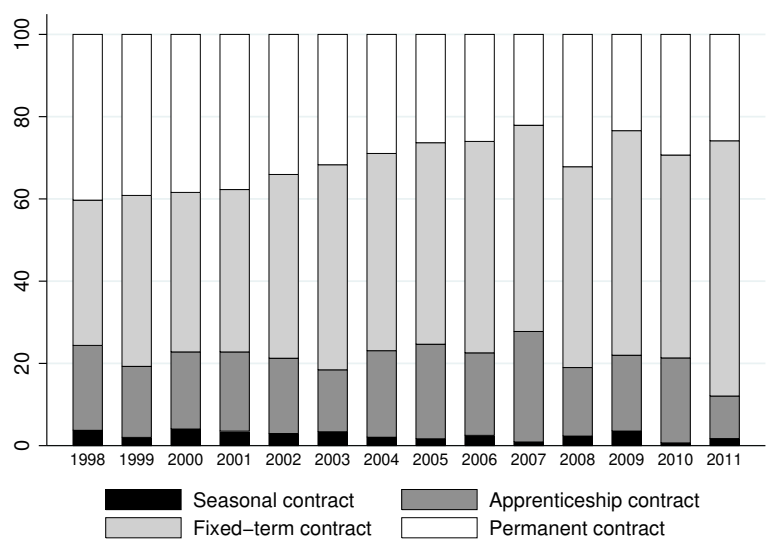

(c) Employment shares, high-education group

Notes: The low-education group includes workers with primary and secondary education degrees, whereas the high-education group includes workers with a tertiary education degree. The shares of unemployed in the high- and low-education groups are not
$11-16 \%$, and the second one ranges in the interval $34-44 \%$. Source: AD-SILC longitudinal dataset.

form of cheap and temporary labour supply (Albanese et al., 2017, Bardazzi and Duranti, 2016, ISFOL, 2010, Steedman, 2012). The Pacchetto Treu revised the apprenticeship by applying the contract to young workers aged 16-26 years for a duration between eighteen months and four years,and by requiring that training ensured by the employer consisted of a theoretical part, which had to take place outside the firm by means of complementary courses, and a practical, firm-based training provided during the work time. Note that the content of the external training was defined by the regional authorities and the collective agreements. In addition, the external training could only be provided by accredited institutes sponsored by regions and had to be no less than 120 hours per year (Albanese et al., 2017). Interestingly, this scheme guaranteed some benefits to the employer, implying a lower labour cost to compensate for the external, formal training, such as a reduction in apprentices' payroll taxes. The worker also contributed to training expenses by taking a wage lower than the wage floor defined by collective bargaining agreements. In addition, the Pacchetto Treu made provisions for monitoring activities, assigned to specific supervisory bodies, over the required training and the formal education outside the workplace. Last, at the end of the training period, apprentices received a certificate for the qualification they had attained. Despite the limitations to compliance with compulsory training obligations by firms (Cappellari et al., 2012), formal training and monitoring represented a commitment device for obliging firms in delivering training, whereas the certification provided a mechanism 
for recognition of workers' occupational skills.

The apprenticeship was then reshaped by the Biagi Law, aiming to stimulate the use of this contract. This target was pursued by several innovations, such as extending the applicability to young people up to age 29 and increasing the contract's duration to a maximum of six years. With respect to the training provision, on the one hand, the reform introduced various types of training, also linked to higher education or university education 8 , and stated that the employer must define the qualification that the worker will acquire during the apprenticeship period and must accordingly provide her/him with training. On the other hand, the reform abolished the certificate of qualifications signed by external authorities and allowed firms to undergo training in the workplace as a substitute for external training courses providing general skills, thus reducing the cost of apprenticeship for firms. With these amendments, it became even more difficult to monitor firms' compliance with the training obligations and to promote the formation of general human capital. The liberalisation of training was coupled with the introduction of a minimum floor to apprentices' wages, stipulated in collective bargaining agreements, to compensate apprentices for the removal of the investment in external training by firms (Tiraboschi, 2012). In addition, the firm's hiring cost of apprentices was subsidised through the guarantee to the employer of some benefits from rebates in apprentices' payroll taxes. Furthermore, according to the reform, apprentices could be hired at a lower level of professional classification with respect to regular workers performing the same tasks, implying a 'de facto' lower wage with respect to the standard.

Figure 2 (panel a) charts the evolution of the employment shares of young (aged 15-29 years) labour market entrants (never employed) in the private sector from the start of the liberalisation of atypical contracts, encompassing the four major contractual typologies of dependent employment. The figure highlights that the use of non-standard contracts has become widespread and that fixed-term and apprenticeship contracts have acquired the most relevant share of entrants in dependent employment for the young workforce in Italy. The share of fixed-term contracts in total dependent employment, in particular, followed a rise after the Biagi Law, when a corresponding decrease in new hiring through permanent contracts occurred. The remaining panels of the figure replicate the previous graph by distinguishing between high- and low-educated young workers. Figure 2 (panel b) shows that before the introduction of the Biagi Law, the apprenticeship contract was the main instrument to hire less-educated workers, whereas afterwards, the relevance of the fixed-term contract sharply increased. Figure 2 (panel c) sketches a somewhat different pattern for higher-educated workers: at the beginning of the analysed period, these workers mainly entered the labour market with a permanent or a fixed-term job, whereas over the years, fixed-term contracts followed an upward trend and gradually became prevalent.

Clearly, Figure 2 indicates that after the liberalisation that created flexibility 'at the margin', employers have generally preferred to hire workers on fixed-term contracts, suggesting that this arrangement was perceived as the most convenient within temporary jobs. According to Bratti et al. (2018), the excessive use of temporary contracts and the short duration of employment spells reduced the incentives for firms to provide training. A complementary explanation is that firms reacted to the unstable economic environment in the late 2000s by increasing fixed-term contracts and reducing apprenticeship contracts, as the training investment would be lost upon the worker's dismissal (Devicienti et al., 2018). Moreover, in a context characterised by high volatility and low long-term investments, it becomes less important for firms to invest in human capital and to use apprenticeship, which emphasises screening through training, to assess workers' quality before getting locked in an open-ended job relationship.

The increased heterogeneity of contractual arrangements in Italy contributed to the rise in earnings inequality among private employees since the end of the 90s and especially after 2006 (Figure 3). Interestingly, in contrast with the common idea that an increase in earnings inequality is mainly due to the worsening economic conditions of young workers compared to the elderly, a further steeper rise in the Gini index of annual earnings and weekly wages emerges when we consider workers aged 15-29 years, showing that the process of deregulation of the Italian labour market was associated with a dramatic increase in 'within younger workers' inequalities'. Therefore, the mobility pattern experienced after the apprenticeship period

${ }^{8}$ The Biagi Law defines three different types of apprenticeships: the vocational apprenticeship, which is largely the most used typology, the apprenticeship for the completion of the right and the duty of education and training, and the apprenticeship aimed at the acquisition of a second-level qualification or tertiary degree. 
Figure 3: Gini index of annual gross earnings inequality among private employees

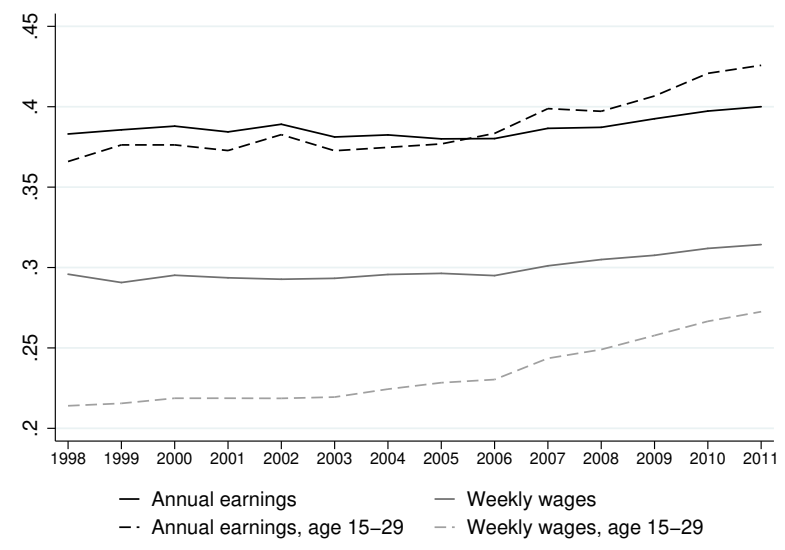

Source: LoSai INPS

might have been a possible driver of this within-group inequality.

\section{Data}

We use the AD-SILC longitudinal dataset, constructed by merging cross-sectional waves from 2004-2012 of IT-SILC (i.e., the Italian component of the European Union Statistics on Income and Living Conditions, EU-SILC), and the administrative longitudinal records provided by the Italian National Social Security Institute (INPS), which track employment and earnings histories of all individuals working in Italy from the moment they entered the labour market up to the end of 20139 In detail, cross-sectional variables collected in IT-SILC concerning all individuals interviewed in the various waves of IT-SILC have been enriched by longitudinal social security records since the entry into the labour market. Social security records offer a comprehensive picture of the careers of all types of Italian workers (both employees and self-employed), as they report on a yearly basis and for each working relationship the gross earnings (including overtime, personal income taxes and social insurance contributions paid by the workers), the working weeks, and the type of working relationship (i.e., public or private employment and the various categories of selfemployment, which are exactly distinguished in INPS archives according to the pension fund where the workers pay pension contributions). Therefore, INPS data allow us to perfectly reconstruct year-by-year the effective labour market experience (in weeks) since the entry into activity or into each working arrangement and the weekly wages (computed by dividing total annual earnings by the corresponding number of worked weeks).

For employees in the private sector, INPS data also record the occupation - distinguishing apprentices, blue-collar workers, white-collar workers and managers - together with the contractual arrangement (fulltime versus part-time and fixed-term versus open-ended), dummies when the worker received allowances for maternity, sickness or temporary job suspension (the so-called Cassa Integrazione allowance), the region of work and some firm's characteristics, namely, the firm code (which allows us to distinguish those who remain in the same firm after the apprenticeship from those who move), the size, the typology (i.e., single firm, leader or follower in a holding) and the industry (coded at the 2-digit NACE level).

Therefore, the AD-SILC dataset couples very detailed information on working histories obtained from social security archives with information on workers' characteristics (gender, age, education, and citizenship) recorded in IT-SILC. Moreover, being based on an administrative source, AD-SILC data are not affected by measurement errors about earnings, worked weeks and the type of contractual arrangement or by memory bias; this is particularly important when studying employment trajectories. For the aim of this article, we

\footnotetext{
${ }^{9}$ We used individual fiscal codes as the matching key.
} 
extracted from this very large dataset (including approximately 4.5 million observations) the longitudinal subsample of those individuals who started to work as an apprentice in the period 1997-2012, followed on a yearly basis up to the last year of observation ${ }^{10}$. We excluded from the sample individuals without Italian citizenship because the retrospective AD-SILC panel has under-represented immigrants in past years.

We aim at inquiring the returns from apprenticeship for those who remained in the firm where they graduated, compared to those who moved after the apprenticeship period to another firm in the same sector or across economic sectors. Since the economic sector is only defined for private employees in INPS data and we want to focus on individuals working as an employee, we dropped workers who moved after the apprenticeship to self-employment or public employment. Finally, since we are interested in analysing returns from apprenticeship for those who move towards a standard occupation, we only considered workers who achieve an open-ended arrangement. Our final sample thus includes 2,804 individuals (1,548 males and 1,256 females) who started to work as an apprentice in 1997 or after and then moved to an open-ended arrangement as a private employee. As expected, our sample is mainly composed of low- and medium-skilled workers; moreover, even if the share of high-skilled workers is not negligible, the shares of individuals with at most a lower secondary, an upper secondary or a tertiary degree are, indeed, $32.7 \%, 55.3 \%$, and $12.0 \%$, respectively (see Appendix A).

We consider three dependent variables in our analyses: the log of gross annual earnings from employment in the private sector, the log of gross weekly wages, and the log of annual weeks worked, where wages and earnings are taken in real terms (nominal values are converted to real values by using CPIs). We consider three dependent variables since they summarise different individuals' outcomes in the labour market: i) 'weekly wages' can be considered the main proxy of a worker's productivity (hourly wages are not available in INPS archives, but we control for the full- versus part-time arrangement in all regressions); ii) 'weeks worked' is an indicator of a worker's employability; and iii) 'annual earnings' is a variable affected by the two previous dimensions and expresses the worker's socio-economic condition in a year.

Our main independent variable is the type of mobility from apprenticeship to the open-ended employment arrangement in the private sector: indeed, we distinguish those who remain in the same firm where they worked as an apprentice from those who switched to a different firm in the same NACE 2-digit industry or to a different industry.

The richness of our dataset allows us to include dozens of covariates in our regressions and to compute (from the full AD-SILC dataset) the instrumental variables we implement. In more detail, in all estimates, we control for the following covariates: individual socio-demographic characteristics (i.e., age, gender, and education), features of the working relationship (i.e., occupation, dummies for part-time workers, dummies for those who spent the longest period in a year receiving maternity, and sickness or job suspension allowances), information about the duration in weeks of the experience as an apprentice, the firm's characteristics that capture some factors related to their productivity (i.e., size and type), and the region of work, year fixed effects and dummies for the year of entry into activity as an open-ended employee in the private sector Appendix A.

individuals in employment at least from one year after graduation from apprenticeship and, then, by restricting the sample to those individuals that we observe at least for the first three years and the first five years in employment after graduation from apprenticeship.

\section{Empirical strategy}

\subsection{Identification and estimation}

To explore different aspects of the human capital formation and career development of apprentices, we consider three outcome variables, viz., annual earnings, annual weeks worked and weekly wages. We compare the outcomes' patterns of stayers with those of job switchers across firms in the same sector and in different economic sectors to infer the impact of training on apprentices' skills and productivity. We estimate pooled

\footnotetext{
${ }^{10}$ To take advantage of the less restricted dimension of the panel, we used the unbalanced panel 1997-2012 to estimate the effects of apprenticeship for individuals in employment at least from one year after graduation from apprenticeship and, then, for individuals observed in employment at least for the first three years and the first five years after graduation from apprenticeship. As a check, we ran the estimates for the balanced panel 1997-2008, and we obtained statistically equivalent results. This analysis is available upon request.
} 
regressions for the selected outcome variables and consider individuals in employment at least from one year after graduation from apprenticeship and, then, individuals that we observe in employment at least for the first three years and the first five years after graduation from apprenticeship.

For a given outcome variable $y_{i t}$, the regression is expressed as follows:

$$
y_{i t}=\beta_{0}+\beta_{1} j o b_{-} s w_{i}+\beta_{2} X_{i t}+\beta_{3} \bar{Z}_{i a}+\gamma_{1} y g_{i}+\gamma_{2} \text { reg }_{i}+\gamma_{4} \text { year }_{t}+\omega_{i t}
$$

where the dummy variable, $j o b \_s w_{i}$, describes job mobility after graduation, $X_{i t}$ is the set of control variables characterising the apprentice after graduation as described in Section $3, \bar{Z}_{i a}$ is a set of controls averaged over the entire length of the apprenticeship, and $a$ is the length of the apprenticeship period $(a=1, \ldots, A)$. All the specifications include the year of graduation, $y g_{i}$, the regional dummies, $r e g_{i}$ and the calendar year, year . $_{\text {. }}$

Several contributions highlight potential negative selection effects in the mobility of the graduate from apprenticeship (Acemoglu and Pischke, 1998, Fitzenberger et al., 2015). During apprenticeship, firms may screen the ability of workers and may choose to retain the most productive after graduation. To solve the bias due to the selection into job mobility, an instrumental variable (IV) approach is applied, exploiting variation in the local labour market characteristics in the year of graduation and over time.

Considering that our endogenous variables are binary variables, in the first stage, we run separate probit regressions for each Italian region, in line with Angrist (2001); Wooldridge (2010); Fitzenberger et al. (2015). Specifically, we run the following auxiliary regression to estimate the probability of mobility $P_{i t}^{r}$ for the region $r(r=1 \ldots, R)$ :

$$
\hat{P}_{i t}^{r}=\alpha_{0}+\alpha_{1} I V_{p t}+\alpha_{2} X_{i t}+\alpha_{3} Z_{i a}+\mu_{i t}
$$

where $I V_{p t}$ is the set of instruments for mobility, which vary at the provincial level (where $p=1, \ldots, P$ and $P$ indicates the Italian provinces). The sum of these probabilities $\left(\hat{P}_{i t}=\sum_{r=1}^{R} \hat{P}_{i t}^{r}\right)$ is the excluded instrument for the endogenous mobility dummy that we use in second-stage regressions. The two-stage procedure allows us to rely on the usual generalised method of moments (GMM) standard errors and test statistics and to run estimates that are robust against misspecification in the probit model (Wooldridge, 2010).

Table 1: Main instrumental variables

\begin{tabular}{rcc}
\hline \hline & Mean & S.d. \\
\cline { 2 - 3 } Unemployment rate & 0.131 & 0.060 \\
Sectoral mobility rates & 0.445 & 0.055 \\
Exit into unemployment & 0.080 & 0.047 \\
Youth unemployment rate & 0.216 & 0.079 \\
Share of high-educated workers & 0.108 & 0.048 \\
Share of low-educated workers & 0.310 & 0.086 \\
\hline \hline
\end{tabular}

Table 1 reports a description of the instruments set, along with the mean and standard deviation of each variable (values of the instrumental variables are taken from the AD-SILC dataset). Following Fitzenberger et al. (2015), we use the unemployment rate to account for the business cycle in general. Sectoral mobility rates and exit into unemployment risk are also used as proxies for further local market characteristics that may affect the mobility of graduates from apprenticeship. Finally, the youth unemployment rate and the shares of high-educated and low-educated workers are introduced, respectively, to account for specific labour market characteristics that are relevant to apprentices who are displaced from their training firm and to capture the educational background of the local workforce.

\subsection{Heterogeneity}

During the analysed time period, we observe apprentices treated by two different regimes. As discussed in Section 2, a major policy change occurred in 2003, i.e., the Biagi Law, which revised the apprenticeship regime formerly introduced by the Pacchetto Treu. In particular, the reform acted on the content of the apprenticeship by allowing firms to remove the component related to general skills; therefore, when investigating the heterogeneous mobility effects under the two regimes, we can infer the effect on the apprentices' prospects of a scheme based on general and specific training (the old apprenticeship) versus a scheme based only on specific training (the new apprenticeship). 
To identify the policy change, we extend the identification originally proposed by Cappellari et al. (2012); d'Agostino et al. (2018), which exploits the gradual application process of the reform, generating independent random events that had no spillover effects on non-adopting regions and sectors. In more detail, the apprenticeship reform required specific regulations to be issued by each Italian region. This process was slow, and in 2005, the government stated that in the absence of regional regulations, collective agreements at the sectoral level could specify the training content of the contract. This produced two tracks before the new apprenticeship contract could be adopted: one covering regional guidelines and the other implemented by sector-specific collective agreements ${ }^{11}$. We use this identification structure to generate a sample of graduates who during their apprenticeship, were treated by the Biagi Law and experienced the new training scheme. Furthermore, as the introduction of the new apprenticeship is an independent event with respect to productive sectors and regions implementing the contract (Cappellari et al., 2012, d'Agostino et al., 2018), we can extend the procedure proposed by Wooldridge (2010) and estimate the following equation:

$$
\begin{aligned}
y_{i t} & =\delta_{0}+\delta_{1} j_{o b} \text { sw }_{i}+\delta_{1}\left(\text { job_sw }_{i} \times \text { biagi }_{i a}\right)+\delta_{2} X_{i t} \\
& +\delta_{3} Z_{i a}+\gamma_{1} y g_{i}+\gamma_{2} \text { reg }_{i}+\gamma_{3} \text { sector }_{i}+\gamma_{4} \text { year }_{t}+\phi_{i t}
\end{aligned}
$$

where biagi $_{i a}$ is a dummy variable that represents whether the employee was treated by the Biagi Law during apprenticeship. To estimate equation 3, in line with Fitzenberger et al. (2015), we introduce one more instrument that is obtained by the interaction between the original instrument and the dummy variable biagi $_{i d}$

\section{Results}

\subsection{IV estimates}

Table 2 to 4 displays the results obtained by the IV estimation for annual earnings, annual weeks worked and weekly wages. In Appendix B we report the ordinary least squares (OLS) estimates. Each table is organised horizontally in three blocks. The first block reports the estimates for the full sample including all job switchers, whereas the second and the third block report, respectively, the estimates for job switchers within the same sector of the training firm and job switchers across other economic sectors. The group of the stayers serves as a comparison throughout the econometric analysis. Each table is organised vertically in three blocks that report the estimation results for the selected outcome variable and consider the individuals at least in the first year of employment after graduation from apprenticeship (1 yr.) and, then, the individuals that we observe, at least, for the first three years (3 yr.) and the first five years $(5 \mathrm{yr}$.) in employment after graduation from apprenticeship.

At the bottom of each block, first-stage weak-instrument test statistics are reported. These statistics, in a one-endogenous variable model, reduce to the standard non-robust (Cragg-Donald F test statistic) and the heteroskedasticity-robust first-stage F-statistic (Kleibergen-Paap F test statistic). As shown in the three tables, the strength of the instruments is confirmed across all the proposed specifications according to the usual criterion that the F-statistic on the excluded instruments in the first stage is greater than 10 .

The results from Table 2 show that the loss in annual earnings when apprentices switch jobs, in comparison to stayers, amounts to approximately $15.5 \%$, and it is persistent over time. Underlying the tenure premium on earnings for workers staying with their initial employer, two sources of change are at play: a $10 \%$ loss in the annual weeks of work (see Table 3) and a loss of approximately $6 \%$ in weekly wages (see Table 4 ).

Moving to the second horizontal block of the three tables, no significant difference emerges comparing stayers to job switchers within the same sector of the training firm in terms of annual earnings and weekly

\footnotetext{
${ }^{11}$ The first regulations were introduced in Emilia-Romagna and Tuscany in 2005, followed by Friuli, Marche, Sardinia and the autonomous province of Bolzano in 2006, and finally by Lazio in 2007. Other regions (Piedmont, Lombardy, Umbria, Abruzzo, Campania, Veneto, Liguria, and Marche) introduced experimental regulations only in some sectors. Moreover, sector-specific collective agreements were introduced in textiles, wood products, chemicals, construction, transportation, retail trade and food products, whose collective agreements were signed in 2005, while metal manufacturing and telecommunication reached agreements in 2006, and tourism and private insurance followed in 2007 (ISFOL 2010).

${ }^{12}$ As shown by Wooldridge (2010), this new instrument, obtained by interacting the original instrument and an exogenous variable, is still a good instrument.
} 
Table 2: IV estimates, annual earnings

\begin{tabular}{|c|c|c|c|c|c|c|}
\hline \multirow[b]{2}{*}{ Full sample } & \multicolumn{2}{|l|}{$1 \mathrm{yr}}$. & \multicolumn{2}{|l|}{$3 \mathrm{yr}}$. & \multicolumn{2}{|l|}{5 yr. } \\
\hline & & & & & & \\
\hline Job switch & $\begin{array}{r}-0.155 \\
(0.038)\end{array}$ & $* * *$ & $\begin{array}{r}-0.149 \\
(0.037)\end{array}$ & $* * *$ & $\begin{array}{r}-0.169 \\
(0.037)\end{array}$ & $* * *$ \\
\hline Cragg-Donald F statistic & 3057.006 & & 3013.652 & & 2823.400 & \\
\hline Kleibergen-Paap F test statistic & 525.167 & & 621.170 & & 652.504 & \\
\hline No. of observations & 13,164 & & 12,704 & & 11,549 & \\
\hline \multicolumn{7}{|l|}{ Within-sector sample } \\
\hline Job switch & $\begin{array}{r}-0.080 \\
(0.051)\end{array}$ & & $\begin{array}{r}-0.076 \\
(0.049)\end{array}$ & & $\begin{array}{r}-0.120 \\
(0.058)\end{array}$ & * \\
\hline Cragg-Donald F statistic & 1491.145 & & 1446.987 & & 1313.693 & \\
\hline Kleibergen-Paap F test statistic & 319.587 & & 361.365 & & 371.225 & \\
\hline No. of observations & 8,041 & & 7,644 & & 6,764 & \\
\hline \multicolumn{7}{|l|}{ Across-sectors sample } \\
\hline Job switch & $\begin{array}{r}-0.207 \\
(0.047)\end{array}$ & $* * *$ & $\begin{array}{r}-0.188 \\
(0.042)\end{array}$ & $* * *$ & $\begin{array}{r}-0.206 \\
(0.040)\end{array}$ & $* * *$ \\
\hline Cragg-Donald F statistic & 2478.024 & & 2461.052 & & 2301.396 & \\
\hline Kleibergen-Paap F test statistic & 454.701 & & 608.155 & & 571.690 & \\
\hline No. of observations & 10,990 & & 10,601 & & 9,613 & \\
\hline
\end{tabular}

Notes: Robust clustered standard errors are in parenthesis. The asterisks stand for the $p$ value significance levels $\left({ }^{*} p<0.1 ;{ }^{* *} p<0.05 ;^{* * *} p<0.01\right)$. The sum of the observations used in the within-sector sample and in the across-sectors sample are not equal to the sum of the observations used for the full-sample analysis, since the information on the stayers in the same firm after graduation is repeated across the sub-samples.

wages. Conversely, graduates from apprenticeship who leave the initial firm, in this case, experience a significant loss of approximately $9 \%$ in the annual weeks worked. This result indicates that training has a positive effect on general skills and productivity of apprentices since they do not suffer a wage loss when quitting the firm. In regard to working time, we argue that the result reveals a decrease in the work time for job switchers caused by labour market frictions, such as informational asymmetries, that make moving to a new firm costly for the trained worker (Acemoglu and Pischke, 1998, 1999b, Leuven, 2005). Indeed, to ascertain whether a worker actually possesses general skills or in what amount or quality, the new employer might only gradually involve the worker in the productive process of the firm. However, we also find that the loss in work activity of within-sector switchers does not fade when we restrict the sample by considering different periods in employment after graduation from apprenticeship. Therefore, the gap in working weeks may be persistent, tending to lessen the potential positive impact of apprenticeship on future returns from training, even in the case of job switchers within the sector where the apprenticeship was performed.

It is worthwhile to highlight a last remark. As we do not find significant differences in wages and earnings between stayers and within-sector switchers, we conjecture that these workers might be used more intensively in the new job through a working-time reduction and a parallel extension of the operational working hours compared to stayers. This setting could represent an efficient solution to overcome information asymmetries, as former apprentices would recoup the gain to training through working overtime (Hart and Ma, 2010), but this practice could also harm job switchers (Pencavel, 2016). We cannot validate this argument with our empirical analysis, but it is instructive to contemplate this possible consequence of mobility.

In contrast, the mobility of graduates to jobs in other economic sectors implies sizeable income disparities compared to stayers. As outlined in the last horizontal block of the three tables, switchers across economic sectors suffer a loss in annual earnings of approximately 21\% (Table 2) and a negative gap in both weeks worked (-13\%, see Table 3) and weekly wages (approximately $-8 \%$, see Table 4 ). The poor performance of graduates moving across sectors under dimensions of both pay and utilisation in the new firms suggests that general skills are not a sufficient component of the apprenticeship programme in Italy; thus, the training content does not provide benefits that can be fully reaped by apprentices later, during the tenure in another firm. In addition, all these effects are persistent, indicating that the loss suffered by job switchers may be long-lasting or even permanent. Therefore, this early labour market event might have large effects on workers 
Table 3: IV estimates, annual weeks worked

\begin{tabular}{|c|c|c|c|c|c|c|}
\hline \multirow[b]{2}{*}{ Full sample } & \multicolumn{2}{|l|}{$1 \mathrm{yr}}$. & \multicolumn{2}{|l|}{$3 \mathrm{yr}}$. & \multicolumn{2}{|l|}{$5 \mathrm{yr}}$. \\
\hline & & & & & & \\
\hline \multirow[t]{2}{*}{ Job switch } & -0.101 & $* * *$ & -0.096 & $* * *$ & -0.103 & $* * *$ \\
\hline & $(0.024)$ & & $(0.024)$ & & $(0.025)$ & \\
\hline Cragg-Donald F statistic & 3059.879 & & 3015.009 & & 2822.150 & \\
\hline Kleibergen-Paap F test statistic & 525.307 & & 620.219 & & 652.410 & \\
\hline No. of observations & 13,153 & & 12,694 & & 11,545 & \\
\hline \multicolumn{7}{|l|}{ Within-sector sample } \\
\hline \multirow[t]{2}{*}{ Job switch } & -0.089 & $* * *$ & -0.082 & $* *$ & -0.099 & $* * *$ \\
\hline & $(0.034)$ & & $(0.034)$ & & $(0.034)$ & \\
\hline Cragg-Donald F statistic & 1492.871 & & 1448.795 & & 1313.405 & \\
\hline Kleibergen-Paap F test statistic & 318.913 & & 361.043 & & 371.132 & \\
\hline No. of observations & 8,035 & & 7,638 & & 6,763 & \\
\hline \multicolumn{7}{|l|}{ Across-sectors sample } \\
\hline \multirow[t]{2}{*}{ Job switch } & -0.131 & $* * *$ & -0.118 & $* * *$ & -0.127 & $* * *$ \\
\hline & $(0.031)$ & & $(0.028)$ & & $(0.027)$ & \\
\hline Cragg-Donald F statistic & 2482.299 & & 2463.122 & & 2300.792 & \\
\hline Kleibergen-Paap F test statistic & 454.927 & & 607.763 & & 571.696 & \\
\hline No. of observations & 10,981 & & 10,593 & & 9,610 & \\
\hline
\end{tabular}

Notes: Robust clustered standard errors are in parenthesis. The asterisks stand for the $p$ value significance levels $\left({ }^{*} p<0.1\right.$; $^{* *} p<0.05$; $\left.{ }^{* * *} p<0.01\right)$. The sum of the observations used in the within-sector sample and in the across-sectors sample are not equal to the sum of the observations used for the full-sample analysis, since the information on the stayers in the same firm after graduation is repeated across the sub-samples.

Table 4: IV estimates, weekly wages

\begin{tabular}{|c|c|c|c|c|c|c|}
\hline \multirow[b]{2}{*}{ Full sample } & \multicolumn{2}{|l|}{$1 \mathrm{yr}}$. & \multicolumn{2}{|l|}{$3 \mathrm{yr}}$. & \multicolumn{2}{|l|}{$5 \mathrm{yr}}$. \\
\hline & & & & & & \\
\hline Job switch & $\begin{array}{r}-0.055 \\
(0.021)\end{array}$ & $* * *$ & $\begin{array}{r}-0.054 \\
(0.021)\end{array}$ & $* * *$ & $\begin{array}{r}-0.066 \\
(0.021)\end{array}$ & $* * *$ \\
\hline Cragg-Donald F statistic & 3059.879 & & 3015.009 & & 2822.150 & \\
\hline Kleibergen-Paap F test statistic & 525.307 & & 620.219 & & 652.410 & \\
\hline No. of observations & 13,153 & & 12,694 & & 11,545 & \\
\hline \multicolumn{7}{|l|}{ Within-sector sample } \\
\hline \multirow[t]{2}{*}{ Job switch } & 0.005 & & 0.002 & & -0.019 & \\
\hline & $(0.027)$ & & $(0.028)$ & & $(0.027)$ & \\
\hline Cragg-Donald F statistic & 1492.871 & & 1448.795 & & 1313.405 & \\
\hline Kleibergen-Paap F test statistic & 318.913 & & 361.043 & & 371.132 & \\
\hline No. of observations & 8,035 & & 7,638 & & 6,763 & \\
\hline \multicolumn{7}{|l|}{ Across-sectors sample } \\
\hline \multirow[t]{2}{*}{ Job switch } & -0.077 & $* * *$ & -0.070 & $* * *$ & -0.080 & $* * *$ \\
\hline & $(0.026)$ & & $(0.025)$ & & $(0.025)$ & \\
\hline Cragg-Donald F statistic & 2482.299 & & 2463.122 & & 2300.792 & \\
\hline Kleibergen-Paap F test statistic & 454.927 & & 607.763 & & 571.696 & \\
\hline No. of observations & 10,981 & & 10,593 & & 9,610 & \\
\hline
\end{tabular}

Notes: Robust clustered standard errors are in parenthesis. The asterisks stand for the $p$ value significance levels $\left({ }^{*} p<0.1 ;{ }^{* *} p<0.05 ;{ }^{* * *} p<0.01\right)$. The sum of the observations used in the within-sector sample and in the across-sectors sample are not equal to the sum of the observations used for the full-sample analysis, since the information on the stayers in the same firm after graduation is repeated across the sub-samples. 
lifetime earnings (von Wachter and Bender, 2006).

In summary, this analysis shows that the apprenticeship contract in Italy has had only a slight positive effect on the transferability of the returns to training for young workers. Indeed, we always find a persistent tenure premium for workers staying with their training firm compared to job switchers. The asymmetrical gains accruing to stayers in comparison to job switchers also point out that the spread of the apprenticeship contract in the Italian firms over the last twenty years has contributed to the increase of disparities in wage profiles and work times of young workers who are supposed to be similar in terms of ability and skills, thus raising inequalities in labour earnings and working conditions.

Finally, it is noteworthy that when we compare these results with the OLS estimates (see Appendix B), we find that the negative effects related to job mobility are generally more pronounced in the IV estimates, suggesting a positive selection bias for stayers in the training firm.

\subsection{Heterogeneous effects: the Biagi reform}

In Section 2 and 4 , we have discussed the major changes in the apprenticeship contract introduced by the Biagi Law. In this section, we assess the heterogeneous effects of mobility produced by the different treatment for graduates with the old Pacchetto Treu apprenticeship scheme and graduates with the new Biagi Law scheme. We expect that staying in the same job should be more rewarding than switching jobs when training is highly firm specific, as under the new apprenticeship regime introduced by the Biagi Law, whereas variations in wages, in relative terms, should be minor when general training is a component of apprenticeship, and thus, graduates have accumulated skills that are in part transferable, as in the case of the old Pacchetto Treu regime.

Table 5: Difference-in-Differences estimates

\begin{tabular}{|c|c|c|c|c|c|c|c|c|c|c|c|c|c|c|c|c|c|c|}
\hline \multirow[b]{3}{*}{ ATE } & \multicolumn{6}{|c|}{ Annual earnings } & \multicolumn{6}{|c|}{ Annual weeks worked } & \multicolumn{6}{|c|}{ Weekly wages } \\
\hline & \multicolumn{2}{|c|}{$\begin{array}{c}\text { Full } \\
\text { sample }\end{array}$} & \multicolumn{2}{|c|}{$\begin{array}{c}\text { Within-sector } \\
\text { sample }\end{array}$} & \multicolumn{2}{|c|}{$\begin{array}{c}\text { Across-sectors } \\
\text { sample }\end{array}$} & \multicolumn{2}{|c|}{$\begin{array}{c}\text { Full } \\
\text { sample }\end{array}$} & \multicolumn{2}{|c|}{$\begin{array}{c}\text { Within-sector } \\
\text { sample }\end{array}$} & \multicolumn{2}{|c|}{$\begin{array}{c}\text { Across-sectors } \\
\text { sample }\end{array}$} & \multicolumn{2}{|c|}{$\begin{array}{c}\text { Full } \\
\text { sample }\end{array}$} & \multicolumn{2}{|c|}{$\begin{array}{c}\text { Within-sector } \\
\text { sample }\end{array}$} & \multicolumn{2}{|c|}{$\begin{array}{c}\text { Across-sectors } \\
\text { sample }\end{array}$} \\
\hline & $\begin{array}{r}-0.007 \\
(0.023)\end{array}$ & & $\begin{array}{r}-0.002 \\
(0.023)\end{array}$ & & $\begin{array}{r}-0.010 \\
(0.023)\end{array}$ & & $\begin{array}{l}-0.093 \\
(0.020)\end{array}$ & $* * *$ & $\begin{array}{r}-0.089 \\
(0.020)\end{array}$ & $* * *$ & $\begin{array}{r}-0.096 \\
(0.020)\end{array}$ & $* * *$ & $\begin{array}{r}0.085 \\
(0.008)\end{array}$ & $* * *$ & $\begin{array}{r}0.086 \\
(0.008)\end{array}$ & $* * *$ & $\begin{array}{r}0.084 \\
(0.008)\end{array}$ & $* * *$ \\
\hline Potential outcome & $\begin{array}{r}9.004 \\
(0.010)\end{array}$ & $* * *$ & $\begin{array}{r}9.001 \\
(0.010)\end{array}$ & $* * *$ & $\begin{array}{r}9.002 \\
(0.010)\end{array}$ & $* * *$ & $\begin{array}{r}3.473 \\
(0.008)\end{array}$ & $* * *$ & $\begin{array}{r}3.472 \\
(0.008)\end{array}$ & $* * *$ & $\begin{array}{r}3.473 \\
(0.008)\end{array}$ & $* * *$ & $\begin{array}{r}5.532 \\
(0.004)\end{array}$ & $* * *$ & $\begin{array}{r}5.531 \\
(0.004)\end{array}$ & $* * *$ & $\begin{array}{r}5.531 \\
(0.004)\end{array}$ & $* * *$ \\
\hline No. of observations & 9322 & & 9098 & & 9205 & & 9321 & & 9097 & & 9204 & & 9320 & & 9096 & & 9203 & \\
\hline
\end{tabular}

Notes: Robust clustered standard errors are in parenthesis. The asterisks stand for the $p$-value significance levels $\left({ }^{*} p<0.1 ;{ }^{* *} p<0.05 ; * * * p<0.01\right)$. The sum of the observations used in the within-sector sample and in the across-sectors sample are not equal to the sum of the observations used for the full-sample analysis, since the information on the stayers in the same firm after graduation is repeated across the sub-samples.

To explore this issue, we first need to check whether any significant difference in the outcome variables for apprentices emerged before graduation under the two schemes. More specifically, potential variations in the effects of mobility might be due to either the change in the training scheme or the change in the features of the contract, such as the introduction of a minimum floor to apprentices' wages, which determined an increase in the average wage relative to the Pacchetto Treu and to the external wage structure of other comparable temporary workers. We could argue that since apprentices were hired at a higher wage in the new apprenticeship regime than in the old regime, after graduation, these workers would have been reluctant to stay in the same firm and accept a lower wage. Thus, the increase in the reservation wage of young people starting an apprenticeship after the Biagi reform might have produced a downward rigidity in wage formation for stayers. This effect may partially mask the larger wage loss for 'new' apprentices switching to other firms, compared to graduates under the old scheme. The rise in the internal wage structure of the apprentices relative to the external wage structure of temporary workers might plausibly have also affected the intensity of their utilisation by employers. For example, the wage compensation could have translated into reducing working time to keep labour cost under control.

To account for these different sources of variation, in the next analysis, we single out a double effect: the first one is due to the change in the terms of the contract that impacts on the outcome variables of workers during apprenticeship and then keeps influencing their behaviour after graduation; the second one is the 'pure' effect of training and firm-specific human capital accumulation.

Table 5 summarises the results from a difference-in-differences (DID) estimation that assesses the whole effect of the change in the apprenticeship regime on the three variables of interest. The average treatment 
effect (ATE), estimated with the DID, is the parameter that allows us to distinguish the causal impact of the policy change for those that have been 'treated' by the new apprenticeship relative to the hypothetical case in which they did not receive the treatment and were hired under the old scheme. The estimation is run by applying an augmented inverse probability weighting (AIPW) model, described in d'Agostino et al. (2018). At the bottom of the table, we report the potential outcome, which represents the level of the variable in the absence of treatment.

The structure of Table 5 is organised in three vertical blocks reporting our outcome variables, i.e., annual earnings, annual weeks worked and weekly wages, for the three samples of graduates used in the previous analysis, i.e., the full sample, the within-sector sample and the across-sectors sample. The first block shows that when annual earnings are accounted for, we do not find any significant difference between 'old' and 'new' apprentices. In contrast, the two remaining blocks show that the apprentices treated by the Biagi Law experience a decrease in weeks worked of $9 \%$ and an increase in weekly wages of almost the same amount during the apprenticeship period. This result may be explained by the fact that the Biagi Law increased the internal structure of apprentice wages as a compensation for the removal of the investment in general training. This may have induced the training firm to reduce the working time of trainees to counterbalance the higher wage paid to them relative to the external structure of wages that was valid for other types of similar young workers. Moreover, our result is invariant across the samples of graduates. The DID result implies that the differences in the outcome variables between 'old' and 'new' apprentices have triggered lasting effects on the behaviour of these variables after graduation.

Figure 4 plots the marginal effects of mobility for graduates with the Biagi apprenticeship scheme, in comparison to graduates with the Pacchetto Treu scheme. We restrict the analysis and consider only the effect after one and three years after graduation. As the new apprenticeship has been gradually implemented since 2005, we cannot consider the effect on the employees that we follow, at least, the first five years in employment after graduation from apprenticeship up to the last available individual observationbecause of the lack of sufficient observations on treated workers.

Figure 4 (panel a) shows marked differences in annual earnings before and after the Biagi reform. At the aggregate level, graduates with the old apprenticeship scheme experience losses in annual earnings of approximately $9 \%$ after switching jobs. Differently, switching jobs implies a loss in annual earnings of approximately $24 \%$ for graduates with the new apprenticeship scheme. Again, this result is invariant across samples.

As in the previous case, we split the factors behind the earnings dynamic in two components, one ascribable to annual weeks worked and the other to weekly wages. Considering the annual weeks worked variable (panel b), the negative difference between stayers and leavers is approximately $6 \%$ under the Pacchetto Treu apprenticeship scheme and approximately $14 \%$ after the introduction of the Biagi Law, with no significant difference across samples. In contrast, in terms of weekly wages (panel c), under the Pacchetto Treu, very small differences emerge between stayers and firm switchers (approximately 3\%), whereas after the policy change, switchers suffer on average a loss of $10 \%$ in the full sample and approximately $17 \%$ in the withinsector and across-sectors samples. This result shows that in the old apprenticeship regime, graduates can quit and be hired by another firm, incurring just a small cost of mobility that is likely due to some frictions in the labour market (Acemoglu and Pischke, 1998, 1999b; Leuven, 2005). In contrast, in the new regime mobility losses are substantial.

By jointly considering the results in Table 5 and Figure 4 and analysing the average effect starting from one year from graduation, we obtain further useful insights. In fact, part of the difference in the performance of the mobility of 'old' and 'new' graduates may be explained with the variation that emerges from the DID analysis and that is due to the change in the apprenticeship regime over time. To disentangle the effect of the change in contractual terms from the 'pure' effect of training, we decompose the marginal effect of 'new' graduates, and we compare it to the marginal effect of 'old' graduates. Table 6reports these marginal effects for annual weeks worked and weekly wages. We omit annual earnings since we do not find any significant result in the DID analysis for this outcome.

Table 6 indicates that job switching leads to a loss in annual weeks worked in almost the same terms for the 'new' graduates and 'old' graduates when we consider the 'pure' training effect. As in the previous analysis, we attribute this result to a drop in weeks worked in comparison to stayers, and the reason lies in some frictions causing a cost of mobility for graduates who quit the training firms. However, interpreting the additional change in the weeks worked engendered by the revised contractual terms (approximately $-9 \%$ in 
Figure 4: Biagi Law, marginal effects

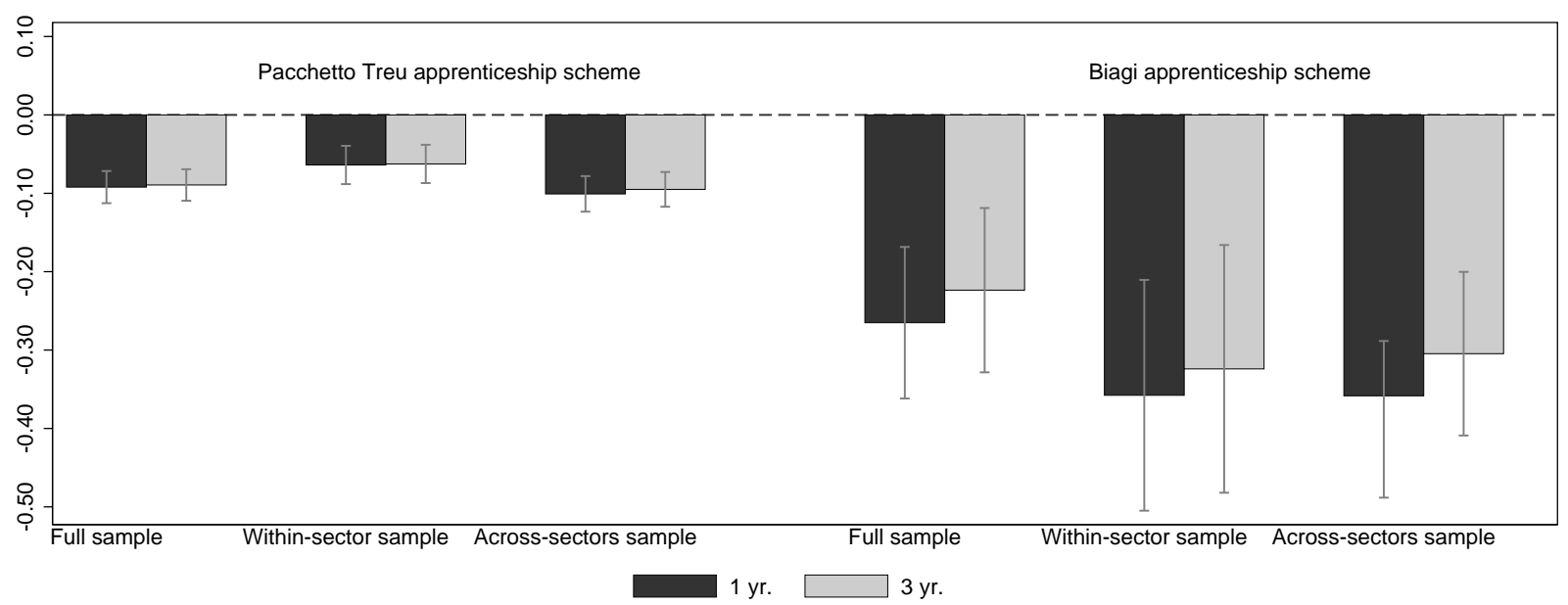

(a) Annual earnings

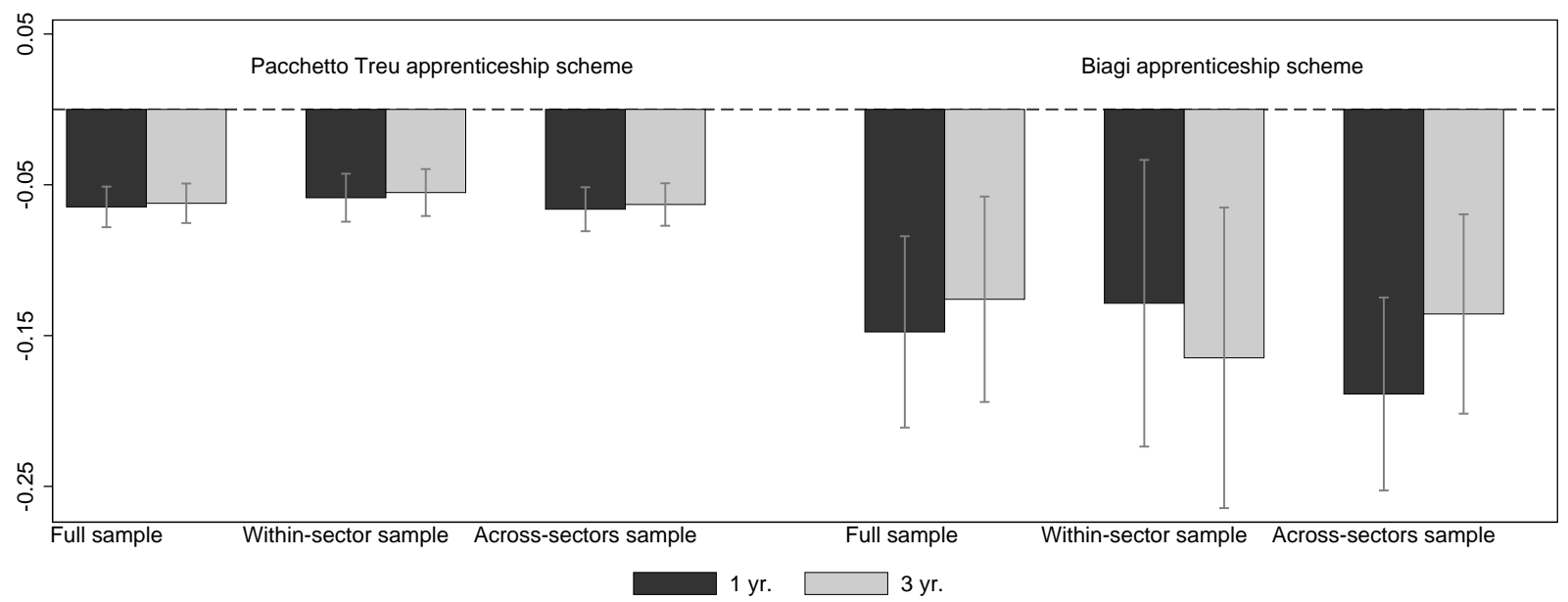

(b) Annual weeks worked

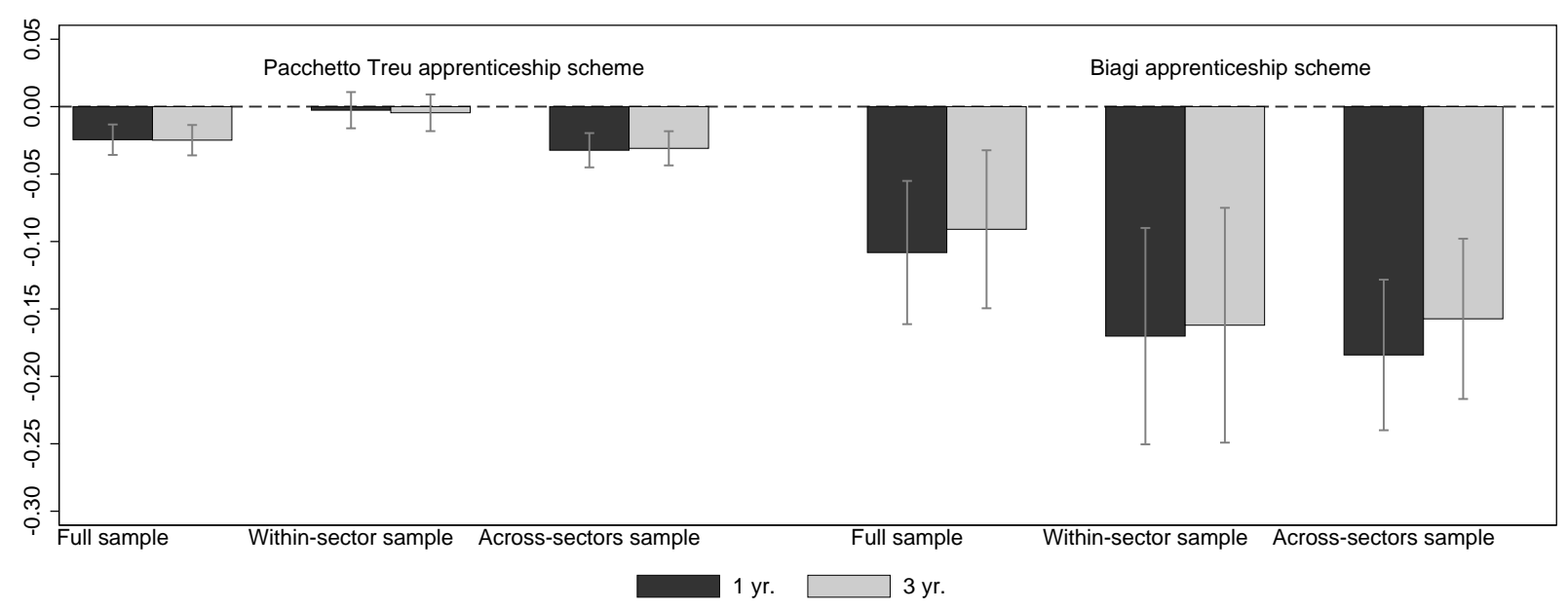

(c) Weekly wages 
all the samples) is challenging. To provide a tentative explanation of this result, we need the complementary evidence on the pattern of wages.

When we analyse weekly wages, the difference between stayers and leavers that can be ascribable to the wage floor is approximately $8.5 \%$, whereas the difference related to the 'pure' training effect is only $1.4 \%$ in the full sample. Interestingly, the gain for stayers that we can attribute to the firm-specific training scheme introduced by the Biagi reform is almost the same order of magnitude of the one that we observe for stayers who were treated with the Pacchetto Treu scheme, which combined general and firm-specific training. Disaggregating the analysis by the type of job switchers yields a more comprehensive story. After the Biagi Law, the emergence of the gain for stayers related to the contractual terms for both samples is approximately $8 \%$, and the gain related to the training component is approximately $8 \%$ for the within-sector sample and nearly $9 \%$ for the across-sectors sample. Comparing this result with the pattern of weekly wages for 'old' apprentices (first column of Table 6), we find that in this last case, graduates who move within sector do not show significant differences with stayers, whereas for across-sectors firm-switchers, the effect of mobility on weekly wages is a loss of approximately $3 \%$. This result means that relative to the apprenticeship scheme designed by the Pacchetto Treu, the Biagi Law determined a more pronounced loss in firm-specific skills of within-sector switchers, worsening the disparities in the outcomes of otherwise similar graduates.

To explain why stayers show a gain in both wages and weeks worked in comparison to job switchers, we argue that firm-specific skills make graduates more productive in the training firm, justifying their higher labour cost and working time relative to graduates moving outside. Beyond the effect of training, we recall that the Biagi Law allowed the firm to hire the apprentice at a lower level of the effective professional classification (livello di inquadramento), implying a 'de facto' lower wage with respect to the formal wage floor. We speculate that the lower effective wage offset the introduction of the wage floor and the risen cost of labour, entailing a higher payoff accruing to the firm for a given number of weeks worked. Conversely, job switchers would be employed in the new job at the formal lower professional status, undertaking the corresponding tasks at a fairly consistent lower wage and shorter working time relative to stayers. This claim is coherent with the study of Devicienti et al. (2018), showing that a large proportion of the growth in wage dispersion in Italy over the period considered in our analysis occurred between job titles defined by collective bargaining institutions.

Table 6: Biagi Law versus Pacchetto Treu, marginal effects

\begin{tabular}{|c|c|c|c|c|c|c|c|c|}
\hline Annual weeks worked & \multicolumn{2}{|c|}{$\begin{array}{l}\text { Pacchetto Treu } \\
\text { Marginal effect }\end{array}$} & \multicolumn{2}{|c|}{ Marginal effect } & \multicolumn{2}{|c|}{$\begin{array}{r}\text { Biagi Law } \\
\text { Marginal effect } \\
\text { contract terms }\end{array}$} & \multicolumn{2}{|c|}{$\begin{array}{c}\text { Marginal effect } \\
\text { pure training }\end{array}$} \\
\hline Full sample & -0.063 & $* * *$ & -0.137 & $* * *$ & -0.093 & $* * *$ & -0.044 & $* * *$ \\
\hline Within-sector sample & -0.061 & $* * *$ & -0.147 & $* * *$ & -0.089 & $* * *$ & -0.058 & $* * *$ \\
\hline Across-sectors sample & -0.065 & $* * *$ & -0.163 & $* * *$ & -0.096 & $* * *$ & -0.067 & $* * *$ \\
\hline \multicolumn{9}{|l|}{ Weekly wages } \\
\hline Full sample & -0.025 & $* * *$ & -0.099 & $* * *$ & -0.085 & $* * *$ & -0.014 & $* * *$ \\
\hline Within-sector sample & -0.004 & & -0.166 & $* * *$ & -0.086 & *** & -0.080 & *** \\
\hline Across-sector sample & -0.031 & $* * *$ & -0.171 & $* * *$ & -0.084 & $* * *$ & -0.087 & $* * *$ \\
\hline
\end{tabular}

Notes: Bootstrapped standard errors $(10,000$ replications $)$ are in parentheses. The asterisks stand for the $p$-value significance levels $\left({ }^{*} p<0.1 ;{ }^{* *} p<0.05 ;{ }^{* * *} p<0.01\right)$.

Overall, we interpret these results as evidence in support of the hypothesis that the mix of firm-specific and general training provided by the old regime allowed apprentices to accumulate some general human capital that could be transferable to other jobs. Regarding the structure of incentives under the Pacchetto Treu, the costs and returns of the general component of training were shared between training firms and apprentices. Following the theoretical literature (Acemoglu and Pischke, 1998, 1999b, Leuven, 2005), this hints that firms might provide general training according to the expected payoffs.

In contrast, the scheme introduced by the Biagi Law narrowed the training opportunities and deepened the lock-in effect of the apprentice with the training firm. Given that the new contract features have not incentivised long-term attachment in training firms, the Biagi Law regime has reduced the bargaining power 
of former apprentices versus the initial employer. Therefore, the new apprenticeship has increased the workers' loss in the case of job mobility, while it has ensured that the training firm can fully capture the advantages of the contract in terms of both the subsidisation of the hiring costs and the rents from the investment in specific human capital. We can conclude that the Biagi reform has weakened the effectiveness of the training scheme in delivering transferable skills to the apprentices and has contributed to increasing inequality in terms of work intensity and pay among otherwise similar young workers and, quite conceivably, among those within the same occupation.

\subsection{Heterogeneous effects: firm size}

Albanese et al. (2017) detect that firm size is an important variable in determining the effects of the new apprenticeship contract on the outcomes of apprentices relative to the counterfactual case in which they would have been hired under the old apprenticeship regime. Indeed, they show that 'new' apprentices hired by firms above the 10-employee threshold have a higher chance of working in a permanent job after graduation. One explanation of the worse performance of the reform in smaller firms is the lack of their capabilities to undertake training investments. However, Albanese et al. (2017) also stress that the Biagi Law introduced a higher tax rebate for firms just below the 10-employee threshold, thus incentivising smaller firms to churn to avoid increasing the size of their permanent staff and triggering the loss of eligibility requirements.

As heterogeneity by firm size is a policy relevant issue, to complete our understanding, we replicate the 'before' and 'after' Biagi Law comparison by distinguishing the two samples of firms below and above the 10-employee threshold and investigate whether the mobility of graduates differently affects our outcome variables. We discuss only the aggregate results to better highlight the major differences in the impact of mobility in small and large firms rather than analyse each effect fully. Appendix C reports a summary of the complete findings, disaggregating the contractual terms effect and the 'pure' effect of training. Similar to the previous analysis, Figure 5 and Figure 6 plot the marginal effects of mobility of graduates with the Biagi apprenticeship scheme compared to graduates with the Pacchetto Treu scheme for smaller and larger firms, respectively.

Considering smaller firms (below the 10-employee threshold), we find a significant negative result for the marginal effect of the Biagi reform on annual earnings (Figure 5 panel a), which is in line with the estimates outlined in Figure 4. Differently, Figure 5 (panel b) shows that the policy change brought about a larger loss in the work time of job switchers compared to stayers (approximately 22\%) and that this result is driven by the difference occurring across economic sectors since the result for within-sector switchers is not significant at the conventional $5 \%$ level. Note that the loss in the number of the annual weeks worked for job switchers was almost $9 \%$ under the Pacchetto Treu apprenticeship scheme invariantly across samples.

Even more telling is the pattern depicted by Figure 5 (panel c), showing that after the Biagi Law, no significant difference between stayers and job switchers emerges when weekly wages are analysed. This result is not striking, given the peculiar Italian industrial context, because it possibly reflects the lack of effective opportunity for training and technologically specific human capital accumulation for the apprentices in smaller firms, which implies that the productivity of workers does not vary whether they remain in the same firm after training or switch employers. Moreover, the fact that we do not find any differential effect on wages ascribable to the contract terms might indicate the vulnerability of workers vis-á-vis employers in the training firm, as well as outside, and the consequent loss of the tenure premium related to the minimum wage.

In light of this result, the wide difference in working time between stayers and switchers shows that the cost of mobility is entirely paid in a non-wage way. However, as we do not find any differential effect in productivity (as proxied by weekly wages), the remarkable gap in work time between stayers and graduates quitting the initial employer might partially conceal the fact that the 'new' graduates can be hired in the training firm at a lower level of their effective professional position, as claimed for the aggregate sample of firms. Hence, as their labour can result underpaid relative to the tasks they undertake, it is conceivable that the working time for stayers is longer than that for switchers.

Looking at the pattern of the outcome variables that show the effects of mobility of graduates in larger firms (above the 10-employee threshold), the picture changes drastically. In this case, graduates with the Biagi Law apprenticeship scheme, after switching jobs, experience a loss in annual earnings of approximately $20 \%$ (Figure 6 panel a) and a loss in weekly wages of approximately $15 \%$ (Figure 6 panel c), with no 
Figure 5: Biagi Law, marginal effects in smaller training firms

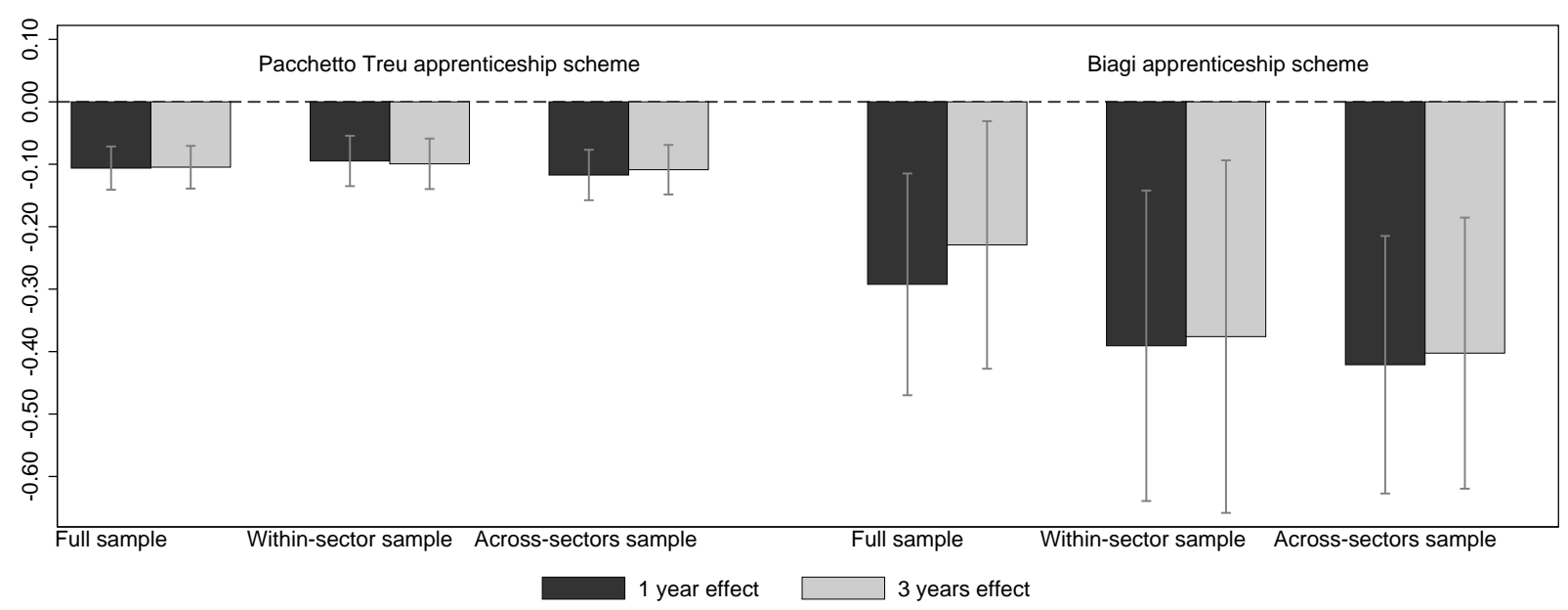

(a) Annual earnings

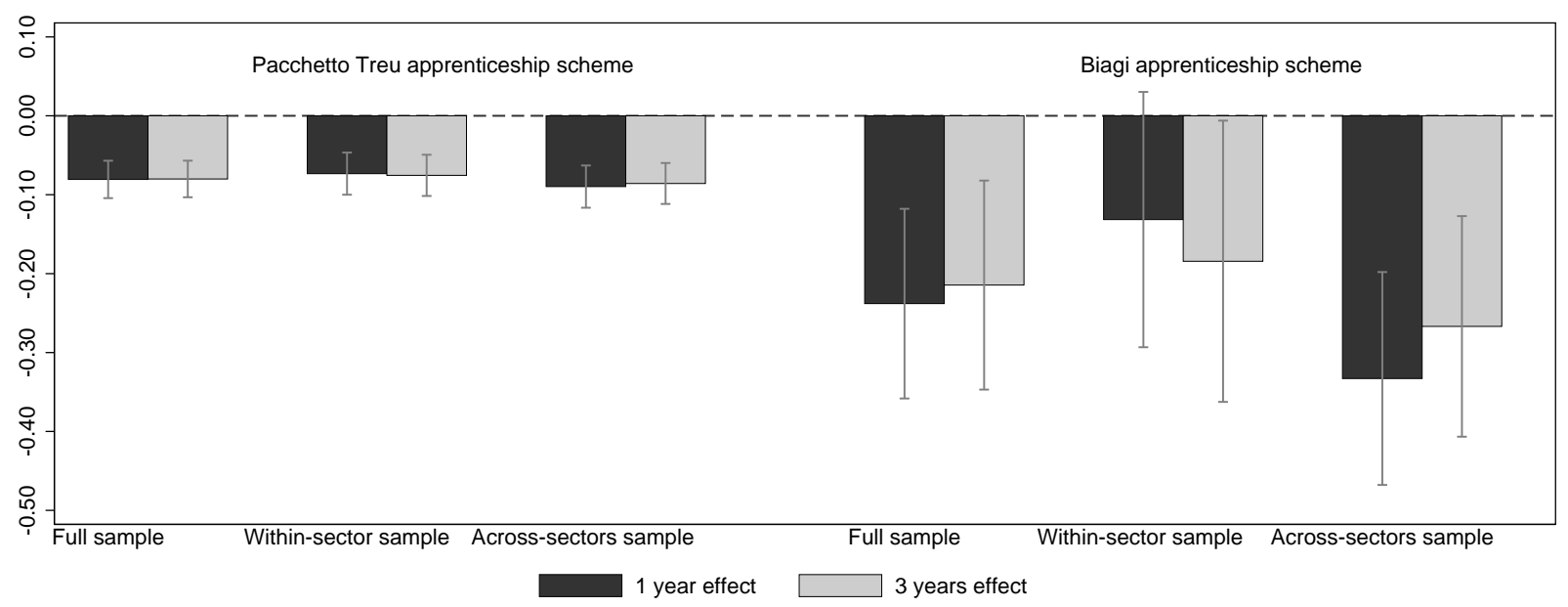

(b) Annual weeks worked

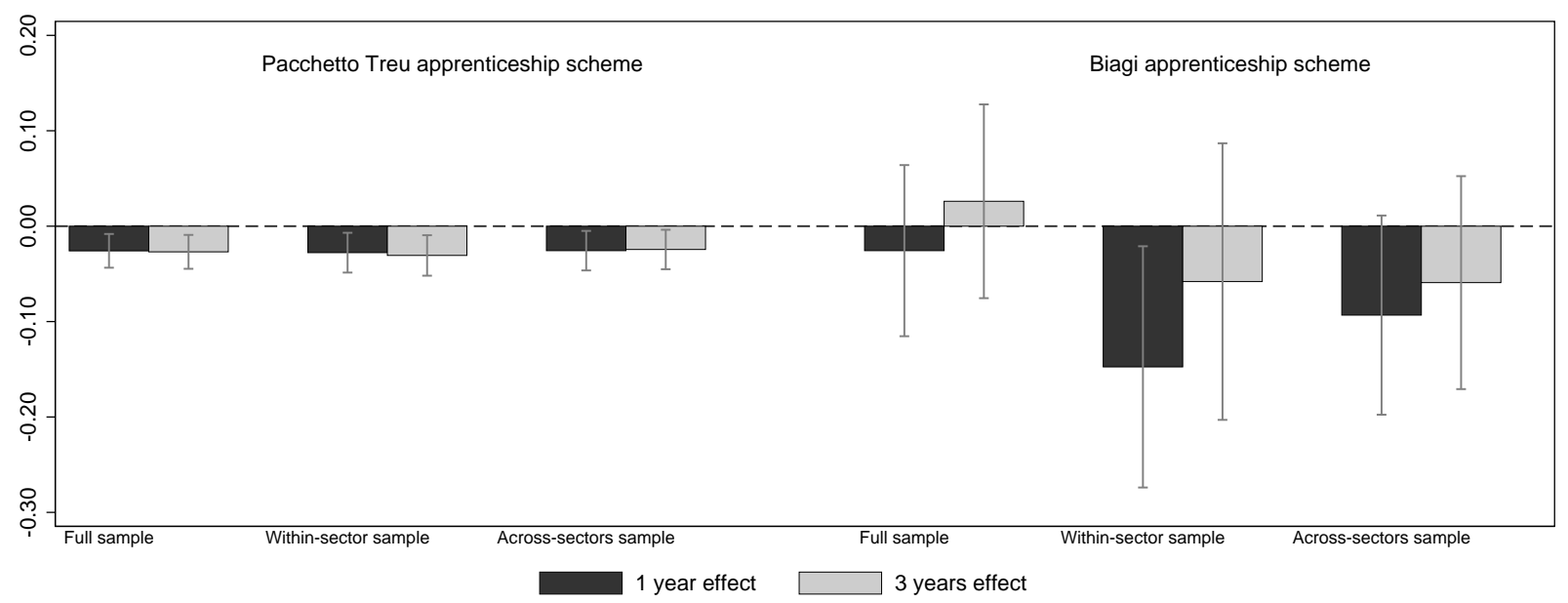

(c) Weekly wages 
Figure 6: Biagi Law, marginal effects in larger training firms

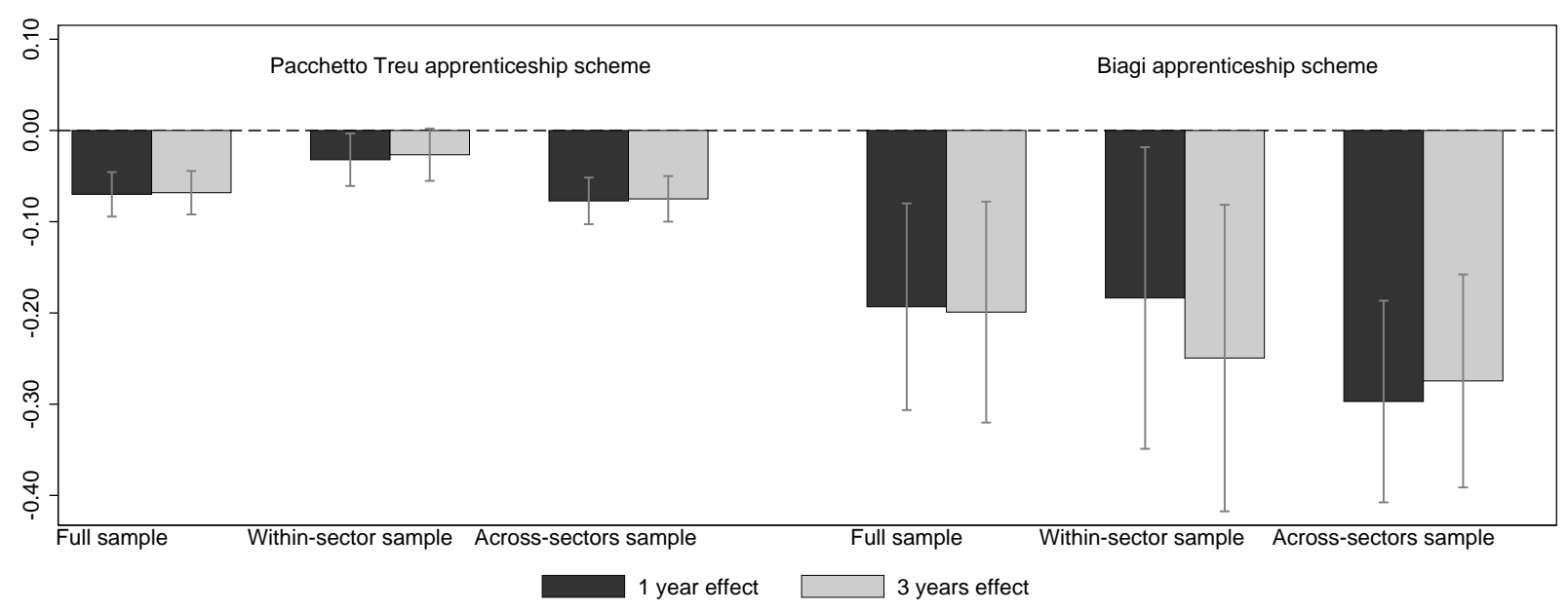

(a) Annual earnings

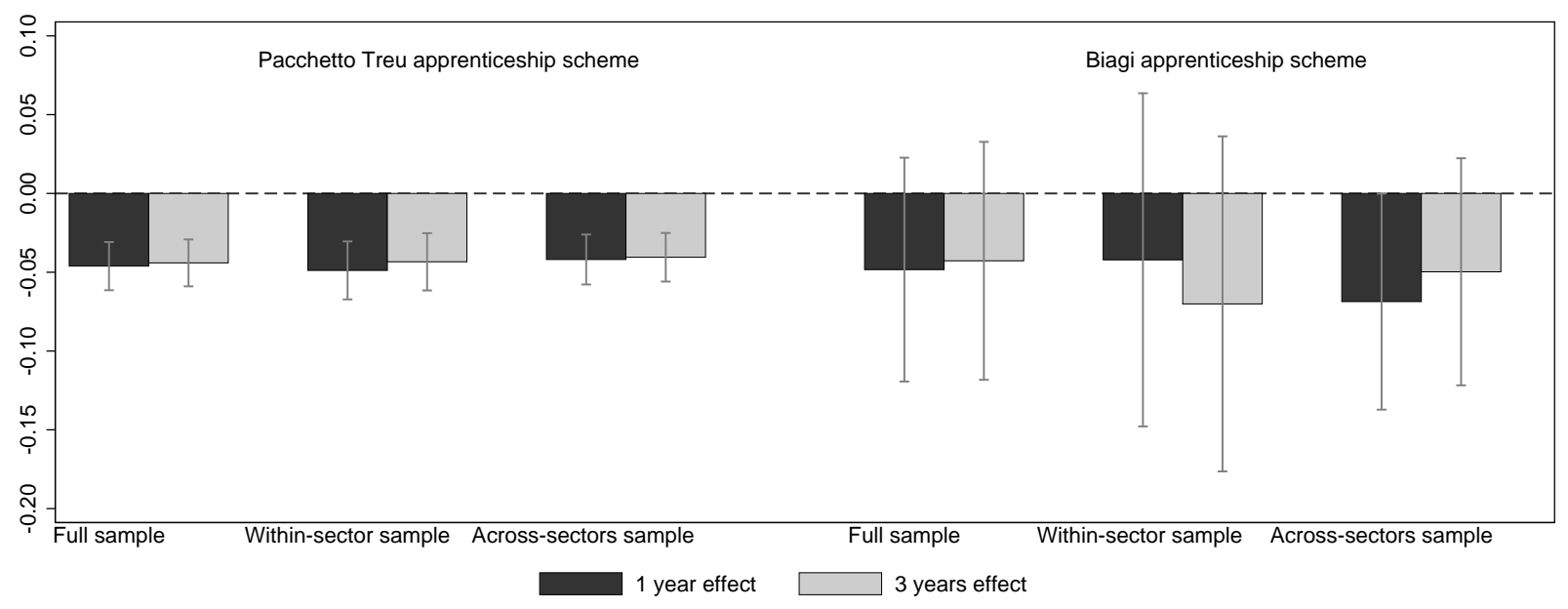

(b) Annual weeks worked

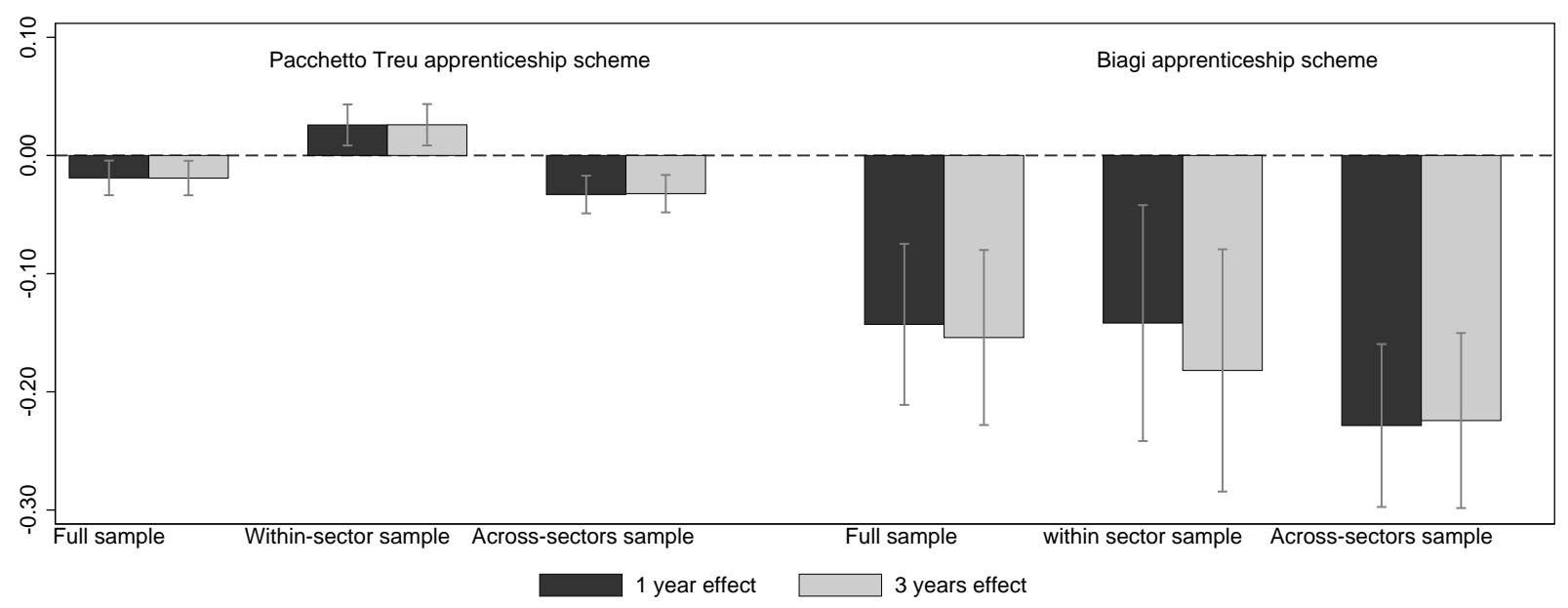

(c) Weekly wages 
significant variation across samples. This result shows that apprentices in larger firms do acquire some technologically firm-specific skills.

Regarding the marginal effects of mobility on the number of weeks worked during a year in larger firms (Figure 6 panel b), a noticeable heterogeneity emerges in comparison to smaller firms. Indeed, the difference between stayers and switchers for this outcome is negligible under the Pacchetto Treu scheme (4.6\%), and it is not significant under the Biagi scheme. The fact that in larger firms, the time of work is similar for apprentices and graduates hired with a permanent job, in the same firm and outside the training firm, is likely to reflect that, first, large firms do use the apprenticeship contract with the purpose of investing in the human capital of young workers more than to exploit apprentices as cheap labour, and second, potential frictions due to informational asymmetries are strongly reduced in the case of turnover among large firms. This further inspection suggests that after the liberalisation of the content of training and the change in the contract terms applied with the Biagi reform, small firms have increasingly used apprentices as mere substitutes for a temporary and cheap labour force to adjust to the business cycle instead of considering their recruitment as a long-term investment decision. Thus, this heterogeneity analysis corroborates the argument that the new arrangements introduced to increase flexibility in the use of apprentices have ultimately weakened the potential positive effects of the contract on young workers' outcomes, with the side-effect of widening inequalities in the distribution of the gains between firms and trained workers and across similar workers, in comparison to the counterfactual of the Pacchetto Treu scheme.

\subsection{Robustness analysis}

To complete the analysis, we first propose a placebo experiment that replicates the main estimation using a sample of workers entering the labour market through a fixed-term contract instead of the apprenticeship. Indeed, as described in Section 2, the fixed-term and apprenticeship contracts are the two most popular typologies of temporary work in Italy, with the main difference in the mandatory provision of training, which is established only for apprentices. The placebo experiment is aimed at investigating whether the results obtained from the previous empirical analysis are due to the effect of the accumulation of human capital through the training provided by apprenticeship or are due to some external — and unobserved - components.

Table 7: Placebo experiment estimates

\begin{tabular}{|c|c|c|c|c|c|c|c|c|c|c|c|c|c|c|}
\hline \multirow{2}{*}{ Full sample } & \multicolumn{5}{|c|}{ Annual earnings } & \multicolumn{6}{|c|}{ Annual weeks worked } & \multicolumn{3}{|c|}{ Weekly wages } \\
\hline & \multicolumn{2}{|l|}{$1 \mathrm{yr}}$. & \multicolumn{2}{|c|}{$3 \mathrm{yr}}$. & $5 \mathrm{yr}$. & \multicolumn{2}{|l|}{$1 \mathrm{yr}$. } & \multicolumn{2}{|c|}{3 yr. } & \multicolumn{2}{|l|}{$5 \mathrm{yr}$. } & 1 yr. & $3 \mathrm{yr}$. & $5 \mathrm{yr}$ \\
\hline Job switch & $\begin{array}{r}-0.138 \\
(0.041)\end{array}$ & $* * *$ & $\begin{array}{r}-0.105 \\
(0.035)\end{array}$ & $* * *$ & $\begin{array}{r}-0.021 \\
(0.030)\end{array}$ & $\begin{array}{r}-0.119 \\
(0.022)\end{array}$ & $* * *$ & $\begin{array}{r}-0.096 \\
(0.017)\end{array}$ & $* * *$ & $\begin{array}{r}-0.045 \\
(0.016)\end{array}$ & $* * *$ & $\begin{array}{r}-0.015 \\
(0.025)\end{array}$ & $\begin{array}{r}-0.005 \\
(0.024)\end{array}$ & $\begin{array}{r}0.024 \\
(0.023)\end{array}$ \\
\hline $\begin{array}{l}\text { Cragg-Donald F statistic } \\
\text { Kleibergen-Paap F test statistic } \\
\text { No. of observations }\end{array}$ & $\begin{array}{r}2447.342 \\
334.626 \\
13,365\end{array}$ & & $\begin{array}{r}2484.390 \\
566.546 \\
12,574\end{array}$ & & $\begin{array}{r}2375.469 \\
632.109 \\
11,346\end{array}$ & $\begin{array}{r}2442.713 \\
332.231 \\
13,347\end{array}$ & & $\begin{array}{r}2478.512 \\
560.715 \\
12,558\end{array}$ & & $\begin{array}{r}2374.684 \\
630.087 \\
11,337\end{array}$ & & $\begin{array}{r}2442.713 \\
332.231 \\
13,347\end{array}$ & $\begin{array}{r}2478.512 \\
560.715 \\
12,558\end{array}$ & $\begin{array}{r}2374.684 \\
630.087 \\
11,337\end{array}$ \\
\hline \multicolumn{15}{|l|}{ Within-sector sample } \\
\hline Job switch & $\begin{array}{r}-0.134 \\
(0.053)\end{array}$ & $* *$ & $\begin{array}{r}-0.092 \\
(0.051)\end{array}$ & * & $\begin{array}{r}-0.028 \\
(0.043)\end{array}$ & $\begin{array}{r}-0.131 \\
(0.035)\end{array}$ & $* * *$ & $\begin{array}{r}-0.088 \\
(0.025)\end{array}$ & $* * *$ & $\begin{array}{r}-0.043 \\
(0.021)\end{array}$ & $* *$ & $\begin{array}{r}-0.007 \\
(0.031)\end{array}$ & $\begin{array}{r}-0.007 \\
(0.034)\end{array}$ & $\begin{array}{r}0.011 \\
(0.035)\end{array}$ \\
\hline $\begin{array}{l}\text { Cragg-Donald F statistic } \\
\text { Kleibergen-Paap F test statistic } \\
\text { No. of observations }\end{array}$ & $\begin{array}{r}1358.597 \\
206.177 \\
8,947\end{array}$ & & $\begin{array}{r}1331.222 \\
306.974 \\
8,398\end{array}$ & & $\begin{array}{r}1258.689 \\
298.124 \\
7,617\end{array}$ & $\begin{array}{r}1358.327 \\
206.590 \\
8,938\end{array}$ & & $\begin{array}{r}1330.376 \\
307.572 \\
8,390\end{array}$ & & $\begin{array}{r}1259.055 \\
297.972 \\
7,611\end{array}$ & & $\begin{array}{r}1358.327 \\
206.590 \\
8,938\end{array}$ & $\begin{array}{r}1330.376 \\
307.572 \\
8,390\end{array}$ & $\begin{array}{r}1259.055 \\
297.972 \\
7,611\end{array}$ \\
\hline \multicolumn{15}{|l|}{ Across-sectors sample } \\
\hline Job switch & $\begin{array}{l}-0.155 \\
(0.046)\end{array}$ & $* * *$ & $\begin{array}{r}-0.116 \\
(0.039)\end{array}$ & $* * *$ & $\begin{array}{r}-0.017 \\
(0.036)\end{array}$ & $\begin{array}{r}-0.127 \\
(0.023)\end{array}$ & $* * *$ & $\begin{array}{r}-0.104 \\
(0.021)\end{array}$ & $* * *$ & $\begin{array}{r}-0.048 \\
(0.019)\end{array}$ & $* * *$ & $\begin{array}{r}-0.020 \\
(0.029)\end{array}$ & $\begin{array}{r}-0.005 \\
(0.028)\end{array}$ & $\begin{array}{r}0.034 \\
(0.027)\end{array}$ \\
\hline $\begin{array}{l}\text { Cragg-Donald F statistic } \\
\text { Kleibergen-Paap F test statistic } \\
\text { No. of observations }\end{array}$ & $\begin{array}{r}1851.699 \\
281.796 \\
11,134\end{array}$ & & $\begin{array}{r}1907.060 \\
454.321 \\
10,451\end{array}$ & & $\begin{array}{r}1830.951 \\
497.391 \\
9,369\end{array}$ & $\begin{array}{r}1846.843 \\
280.428 \\
11,117\end{array}$ & & $\begin{array}{r}1901.386 \\
451.821 \\
10,436\end{array}$ & & $\begin{array}{r}1830.190 \\
497.398 \\
9,361\end{array}$ & & $\begin{array}{r}1846.843 \\
280.428 \\
11,117\end{array}$ & $\begin{array}{r}1901.386 \\
451.821 \\
10,436\end{array}$ & $\begin{array}{r}1830.190 \\
497.398 \\
9,361\end{array}$ \\
\hline
\end{tabular}

Notes: Robust clustered standard errors are in parenthesis. The asterisks stand for the $p$-value significance levels $\left({ }^{*} p<0.1 ;{ }^{* *} p<0.05 ;{ }^{* * *} p<0.01\right)$. The sum of the observations used in the within-sector sample and in the across-sectors sample are not equal to the sum of the observations used for the full-sample analysis, since the information on the stayers in the same firm after graduation is repeated across the sub-samples.

Table 7 reports the main results of the experiment, using the same structure proposed in Table 2, 3 and 4. Throughout the three different samples, we find significant results only for the outcome variables weeks worked and annual earnings. In contrast, no significant result emerges regarding weekly wages. Hence, the 
fixed-term contract affects the young employees' work time after placement in a permanent contract, but it does not impact on their human capital. Furthermore, the impact on earnings is only temporary. This result suggests that the proposed instrumental variable approach is suitable to remove the self-selection bias from the assessment of the impact of apprenticeship on our outcome variables.

Second, we propose a replication of the analysis on the heterogeneous effects by firm size in Section 5.3 by using a different threshold for smaller and larger firms as a robustness check. More specifically, during the observed period, the legislation envisaged size-contingent firing restrictions according to which firing costs increased sharply above the 15-employee threshold. Bratti et al. (2018) use this threshold to provide causal evidence on the effect of EPL on firm-provided training by running a regression discontinuity design (RDD). This study finds that larger firms made more extensive use of temporary workers who are less protected by the legislation and that the higher worker turnover reduced the number of trained workers. Thus, we might expect that the threshold of higher EPL would differently affect the training provision to incumbent apprentices in firms below and above it and, in turn, would influence the impact of mobility of graduates on the pattern of the outcome variables. We refer to for the results of this robustness check. Comparing these estimates with the results presented in Section 5.3, we find that the effects of mobility are markedly heterogeneous by the size of firms, with no significant difference between the two thresholds for the number of employees.

Finally, we replicate the comparative analysis of the marginal effect of mobility under the old and new apprenticeship scheme, proposed in Figure 4 , by restricting the sample to the workers in the age range 18-26 years who entered the labour market with an apprenticeship contract. Indeed, the Pacchetto Treu restricted the use of the apprenticeship contract to young workers in the age range 15-26 years, whereas the vocational apprenticeship, which is largely the most used typology after the introduction of the Biagi Law, involves young workers in the age range 18-29 years. As a consequence, in this robustness check, we consider a more homogeneous group of workers eligible for the apprenticeship contract under the two different schemes. As shown in the figure presented in Appendix E, the results do not change when we use this age range.

\section{Conclusions}

Using a new longitudinal dataset for Italy, this paper extends the approach of Fitzenberger et al. (2015) and provides causal estimates of the effects of mobility after graduation of apprentices on three outcome variables, viz. annual earnings, annual weeks worked and weekly wages. From this analysis, we infer how the training provision impacts on skills and human capital of apprentices and whether apprenticeship training is sufficiently general to be valuable to other firms within the same economic sector or across sectors. We adopt an instrumental variable approach, exploiting time and regional variation of labour market characteristics to control for selection bias and confounding factors. A related issue that we empirically investigate is the effect of the Biagi Law, which liberalised the training scheme and revised some features of the apprenticeship contract terms. To this aim, we assess the causal impact of the new apprenticeship on the selected outcome variables, in comparison to the counterfactual of the old apprenticeship regime established by the Pacchetto Treu. From this analysis, we infer the differential effect of a scheme based on general and specific training (the old apprenticeship) versus a scheme based only on specific training (the new apprenticeship).

Using the stayers as the comparison group, we find that job switchers who changed economic sectors faced a significant reduction in both wages and intensity of work supplied and performed worse than job switchers who remained in the same sector of the training firm, indicating a loss of firm-specific human capital. In addition, our findings suggest that the arrangements of the training scheme set by the Biagi reform have further reduced the transferability of skills of graduates from apprenticeship. Allowing for heterogeneity by firm size, this study shows large differences in the patterns of the outcome variables for graduates under the new regime, with workers employed in smaller firms standing out as the least privileged. This result is compatible with the hypothesis that after the labour market deregulation implemented with the Biagi reform, the training provision delivered by small firms has been inadequate.

From the perspective of the impact on labour market equality, our estimates show the following: first, significant disparities among graduates from apprenticeship have emerged in terms of work intensity and pay, and second, these disparities have increased after the liberalisation of the contract introduced by the Biagi Law. Overall, the evidence provided by our analysis suggests that the spread of the apprenticeship contract in Italy over the last twenty years might have contributed to increasing the labour earnings inequality among 
similar young workers. This result is particularly relevant to understanding possible mechanisms driving the emergence of within inequalities in the Italian labour market.

The policy implication drawn from the empirical analysis proposed in this paper is that training policies in Italy should be entirely reformed to improve both efficiency and equity. In addition, our findings on the revision of the apprenticeship contract may serve as a paradigmatic assessment that casts doubts on the effectiveness of measures only aimed at liberalising the labour market to improve its functioning. In contrast, our analysis seems to underpin the view that leashing market forces within appropriate institutional settings and taking corrective measures for unacceptable inequalities would be preferable policy choices to cope with the unfolding issues in contemporary labour markets. 


\section{Appendix A. Descriptive statistics}

\begin{tabular}{|c|c|c|c|c|}
\hline & Stayers & $\begin{array}{l}\text { Within-sector } \\
\text { switchers }\end{array}$ & $\begin{array}{l}\text { Across-sectors } \\
\text { switchers }\end{array}$ & Total \\
\hline \multicolumn{5}{|c|}{ Outcome variables } \\
\hline Annual earnings (log) & 9.877 & 9.762 & 9.81 & 9.832 \\
\hline Annual weeks worked (log) & 3.905 & 3.819 & 3.839 & 3.865 \\
\hline Weekly wages (log) & 5.976 & 5.947 & 5.976 & 5.971 \\
\hline \multicolumn{5}{|c|}{ Main covariates } \\
\hline \multicolumn{5}{|l|}{ Gender } \\
\hline Male & 54.490 & 52.552 & 57.083 & 55.189 \\
\hline Female & 45.510 & 47.448 & 42.917 & 44.811 \\
\hline Age & 26.938 & 27.611 & 27.71 & 27.351 \\
\hline \multicolumn{5}{|l|}{ Education } \\
\hline Primary & 26.153 & 34.188 & 27.731 & 28.092 \\
\hline Secondary & 61.119 & 55.195 & 58.519 & 59.127 \\
\hline Tertiary & 12.729 & 10.618 & 13.750 & 12.781 \\
\hline \multicolumn{5}{|l|}{ Occupation } \\
\hline Blue collar & 38.454 & 34.640 & 39.882 & 38.387 \\
\hline White collar & 61.546 & 65.360 & 60.118 & 61.613 \\
\hline Apprenticeship average weekly wage (log) & 5.655 & 5.585 & 5.54 & 5.598 \\
\hline Term of the apprenticeship (total weeks worked) & 209.606 & 155.7 & 117.494 & 164.626 \\
\hline \multicolumn{5}{|l|}{ Part-time } \\
\hline no & 88.218 & 83.379 & 83.218 & 85.462 \\
\hline yes & 11.782 & 16.621 & 16.782 & 14.538 \\
\hline \multicolumn{5}{|l|}{ Maternity leave } \\
\hline no & 98.616 & 98.314 & 98.568 & 98.547 \\
\hline yes & 1.384 & 1.686 & 1.432 & 1.453 \\
\hline \multicolumn{5}{|l|}{ Job suspension allowance } \\
\hline no & 99.426 & 99.727 & 99.351 & 99.446 \\
\hline yes & 0.574 & 0.273 & 0.649 & 0.554 \\
\hline \multicolumn{5}{|l|}{ Biagi Law } \\
\hline no & 89.635 & 91.067 & 91.753 & 90.701 \\
\hline yes & 10.365 & 8.933 & 8.247 & 9.299 \\
\hline \multicolumn{5}{|l|}{ Firm type } \\
\hline Main firm & 1.435 & 4.786 & 5.660 & 3.642 \\
\hline Secondary & 7.582 & 8.706 & 17.208 & 11.539 \\
\hline Single firm & 90.983 & 86.509 & 77.132 & 84.819 \\
\hline Firm size & 258.508 & 529.782 & 1786.912 & 995.992 \\
\hline
\end{tabular}




\section{Appendix B. OLS estimates}

\begin{tabular}{|c|c|c|c|c|c|c|c|c|c|c|c|c|c|c|c|c|c|c|}
\hline \multirow{2}{*}{ Full sample } & \multicolumn{6}{|c|}{ Annual earnings } & \multicolumn{6}{|c|}{ Annual weeks worked } & \multicolumn{6}{|c|}{ Weekly wage } \\
\hline & \multicolumn{2}{|l|}{$1 \mathrm{yr}$. } & \multicolumn{2}{|c|}{3 yr. } & \multicolumn{2}{|l|}{5 yr. } & \multicolumn{2}{|l|}{$1 \mathrm{yr}$. } & \multicolumn{2}{|c|}{$3 \mathrm{yr}$. } & \multicolumn{2}{|l|}{5 yr. } & \multicolumn{2}{|l|}{$1 \mathrm{yr}$. } & \multicolumn{2}{|c|}{$3 \mathrm{yr}$. } & \multicolumn{2}{|l|}{$5 \mathrm{yr}$. } \\
\hline Job switch & $\begin{array}{r}-0.077 \\
(0.016)\end{array}$ & $* * *$ & $\begin{array}{r}-0.073 \\
(0.017)\end{array}$ & $* * *$ & $\begin{array}{r}-0.081 \\
(0.015)\end{array}$ & $* * *$ & $\begin{array}{c}-0.062 \\
(0.008)\end{array}$ & $* * *$ & $\begin{array}{r}-0.058 \\
(0.008)\end{array}$ & $* * *$ & $\begin{array}{r}-0.061 \\
(0.008)\end{array}$ & $* * *$ & $\begin{array}{r}-0.018 \\
(0.010)\end{array}$ & * & $\begin{array}{r}-0.018 \\
(0.011)\end{array}$ & $*$ & $\begin{array}{r}-0.019 \\
(0.011)\end{array}$ & * \\
\hline $\begin{array}{l}R^{2} \\
\text { Adjusted } R^{2} \\
\text { No. of observations }\end{array}$ & $\begin{array}{r}0.367 \\
0.363 \\
13225\end{array}$ & & $\begin{array}{r}0.360 \\
0.356 \\
12764\end{array}$ & & $\begin{array}{r}0.376 \\
0.373 \\
11600\end{array}$ & & $\begin{array}{r}0.123 \\
0.119 \\
13214\end{array}$ & & $\begin{array}{r}0.112 \\
0.108 \\
12754\end{array}$ & & $\begin{array}{r}0.104 \\
0.099 \\
11596\end{array}$ & & $\begin{array}{r}0.523 \\
0.520 \\
13214\end{array}$ & & $\begin{array}{r}0.518 \\
0.516 \\
12754\end{array}$ & & $\begin{array}{r}0.531 \\
0.529 \\
11596\end{array}$ & \\
\hline \multicolumn{19}{|l|}{ Within-sector sample } \\
\hline Job switch & $\begin{array}{r}-0.044 \\
(0.022)\end{array}$ & $* *$ & $\begin{array}{r}-0.046 \\
(0.022)\end{array}$ & $* *$ & $\begin{array}{r}-0.060 \\
(0.021)\end{array}$ & $* * *$ & $\begin{array}{r}-0.051 \\
(0.011)\end{array}$ & $* * *$ & $\begin{array}{r}-0.051 \\
(0.011)\end{array}$ & $* * *$ & $\begin{array}{r}-0.056 \\
(0.011)\end{array}$ & $* * *$ & $\begin{array}{r}0.004 \\
(0.013)\end{array}$ & & $\begin{array}{r}0.001 \\
(0.014)\end{array}$ & & $\begin{array}{r}-0.002 \\
(0.014)\end{array}$ & \\
\hline $\begin{array}{l}R^{2} \\
\text { Adjusted } R^{2} \\
\text { No. of observations }\end{array}$ & $\begin{array}{r}0.383 \\
0.378 \\
8054\end{array}$ & & $\begin{array}{r}0.370 \\
0.364 \\
7656\end{array}$ & & $\begin{array}{r}0.381 \\
0.375 \\
6771\end{array}$ & & $\begin{array}{r}0.124 \\
0.116 \\
8048\end{array}$ & & $\begin{array}{r}0.113 \\
0.105 \\
7650\end{array}$ & & $\begin{array}{r}0.097 \\
0.088 \\
6770\end{array}$ & & $\begin{array}{r}0.552 \\
0.548 \\
8048\end{array}$ & & $\begin{array}{r}0.540 \\
0.536 \\
7650\end{array}$ & & $\begin{array}{r}0.545 \\
0.541 \\
6770\end{array}$ & \\
\hline \multicolumn{19}{|l|}{ Across-sectors sample } \\
\hline Job switch & $\begin{array}{r}-0.083 \\
(0.020)\end{array}$ & $* * *$ & $\begin{array}{r}-0.075 \\
(0.020)\end{array}$ & $* * *$ & $\begin{array}{r}-0.087 \\
(0.018)\end{array}$ & $* * *$ & $\begin{array}{r}-0.065 \\
(0.010)\end{array}$ & $* * *$ & $\begin{array}{r}-0.058 \\
(0.010)\end{array}$ & $* * *$ & $\begin{array}{r}-0.062 \\
(0.009)\end{array}$ & $* * *$ & $\begin{array}{r}-0.023 \\
(0.013)\end{array}$ & $*$ & $\begin{array}{r}-0.022 \\
(0.013)\end{array}$ & $*$ & $\begin{array}{r}-0.024 \\
(0.013)\end{array}$ & $*$ \\
\hline $\begin{array}{l}R^{2} \\
\text { Adjusted } R^{2} \\
\text { No. of observations }\end{array}$ & $\begin{array}{r}0.372 \\
0.368 \\
11044\end{array}$ & & $\begin{array}{r}0.367 \\
0.363 \\
10655\end{array}$ & & $\begin{array}{r}0.392 \\
0.388 \\
9663\end{array}$ & & $\begin{array}{r}0.120 \\
0.114 \\
11035\end{array}$ & & $\begin{array}{r}0.111 \\
0.105 \\
10647\end{array}$ & & $\begin{array}{r}0.105 \\
0.099 \\
9660\end{array}$ & & $\begin{array}{r}0.525 \\
0.522 \\
11035\end{array}$ & & $\begin{array}{r}0.522 \\
0.519 \\
10647\end{array}$ & & $\begin{array}{r}0.536 \\
0.532 \\
9660\end{array}$ & \\
\hline
\end{tabular}

Notes: Robust clustered standard errors are in parentheses. The asterisks stand for the $p$-value significance levels $\left({ }^{*} p<0.1 ;{ }^{* *} p<0.05 ;{ }^{* * *} p<0.01\right)$. The sums of the observations used in the within-sector sample and in the across-sectors sample are not equal to the sum of the observations used for the full-sample analysis since the information on the stayers in the same firm after graduation is repeated across the sub-samples. 


\section{Appendix C. Heterogeneous effects by firm size (10-employee threshold), marginal effects}

Table C.1: Difference-in-Differences estimates

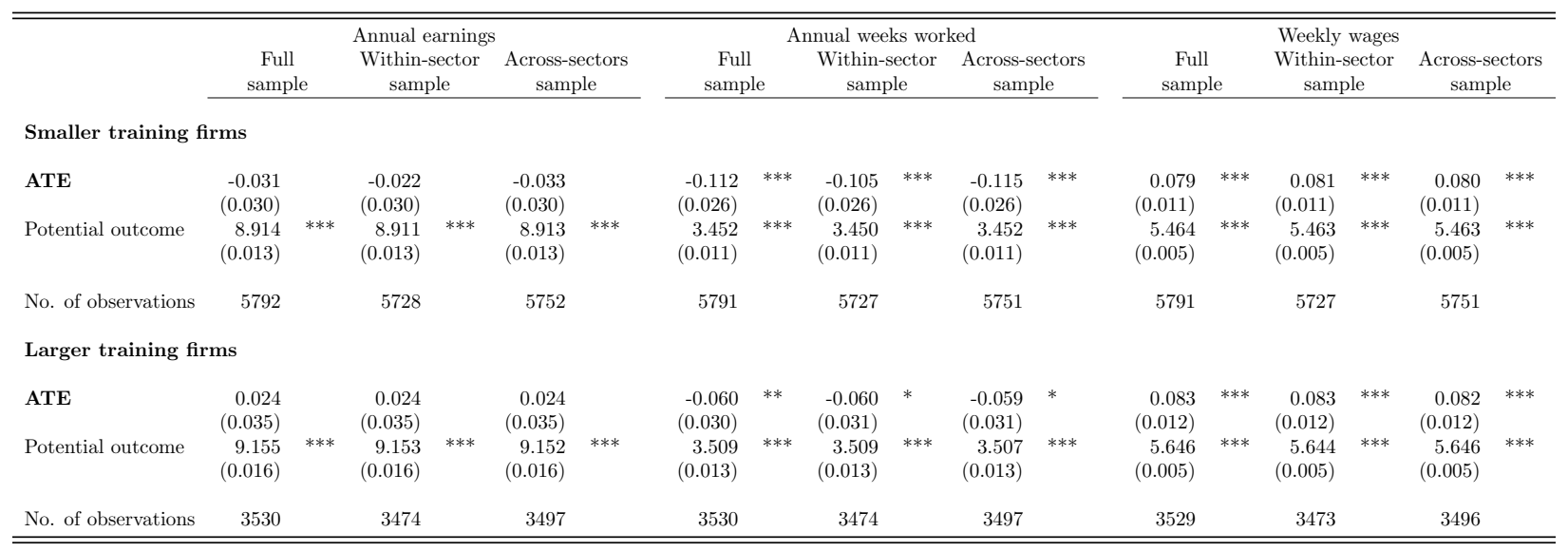

Notes: Robust clustered standard errors are in parenthesis. The asterisks stand for the $p$-value significance levels $\left({ }^{*} p<0.1 ;{ }^{* *} p<0.05 ;{ }^{* * *} p<0.01\right)$. The sum of the observations used in the within-sector sample and in the across-sectors sample are not equal to the sum of the observations used for the full-sample analysis, since the information on the stayers in the same firm after graduation is repeated across the sub-samples.

Table C.2: Biagi Law versus Pacchetto Treu, marginal effects

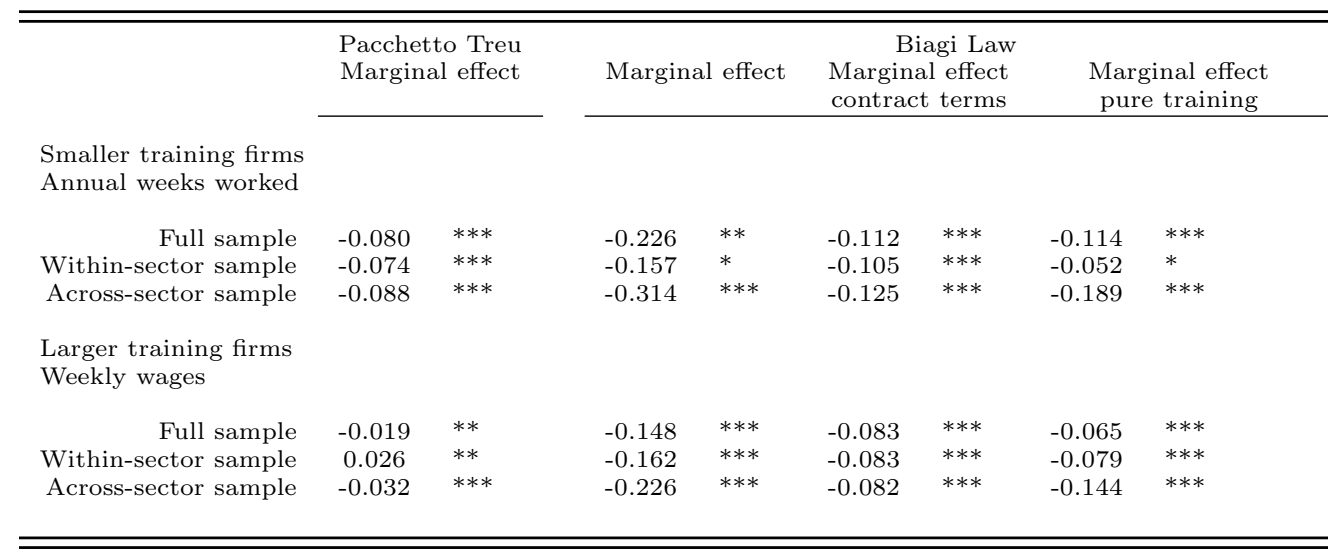

Notes: Bootstrapped standard errors (10,000 replications) are in parentheses. The asterisks stand for the $p$-value significance levels $\left({ }^{*} p<0.1 ;^{* *} p<0.05 ;{ }^{* * *} p<0.01\right)$. 
Appendix D. Heterogeneous effects by firm size (15-employee threshold), marginal effects

Figure D.1: Biagi Law, marginal effects in smaller training firms

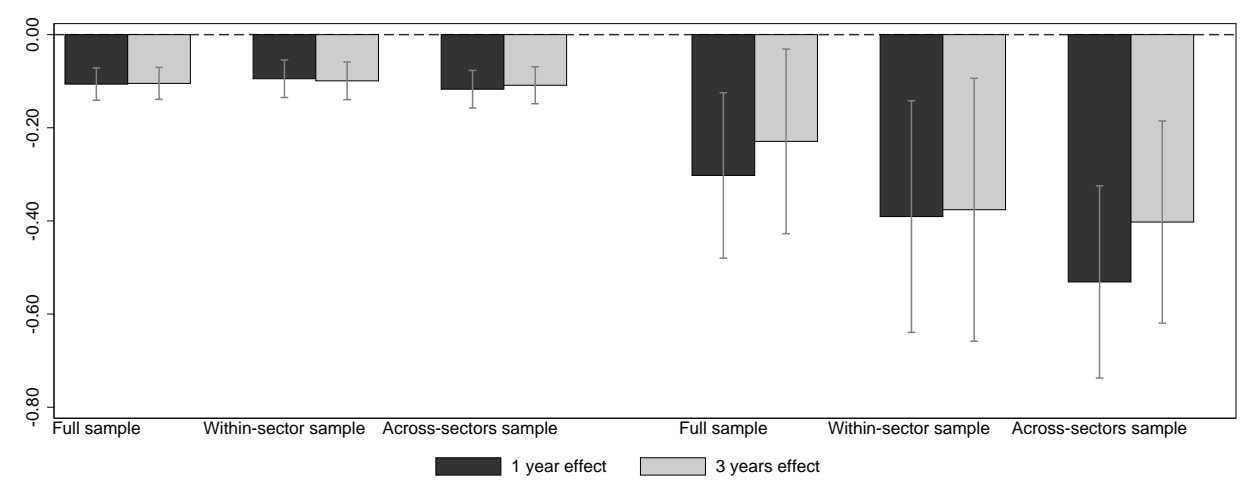

(a) Annual earnings

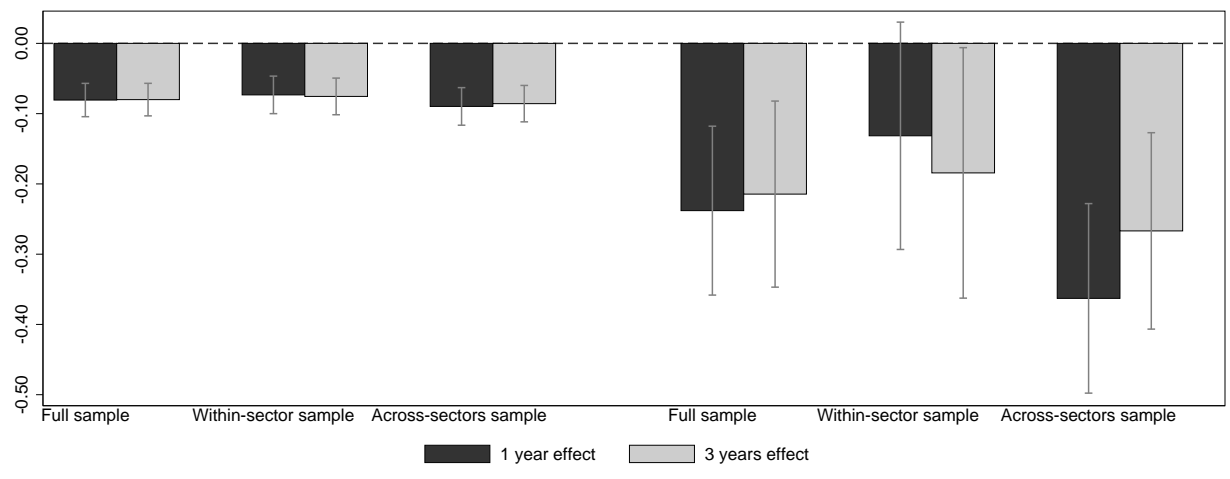

(b) Annual weeks worked

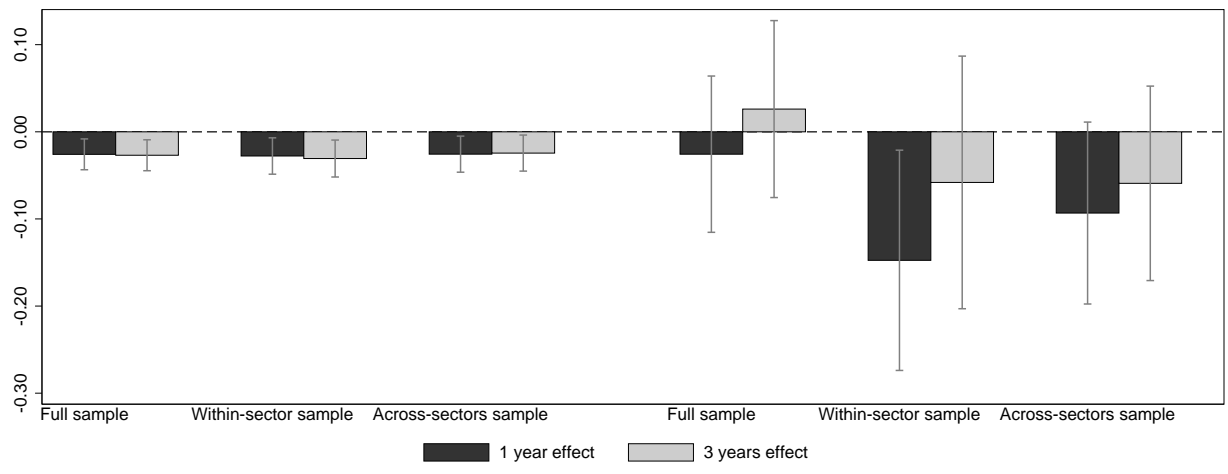

(c) Weekly wages 
Figure D.2: Biagi Law, marginal effects in larger training firms

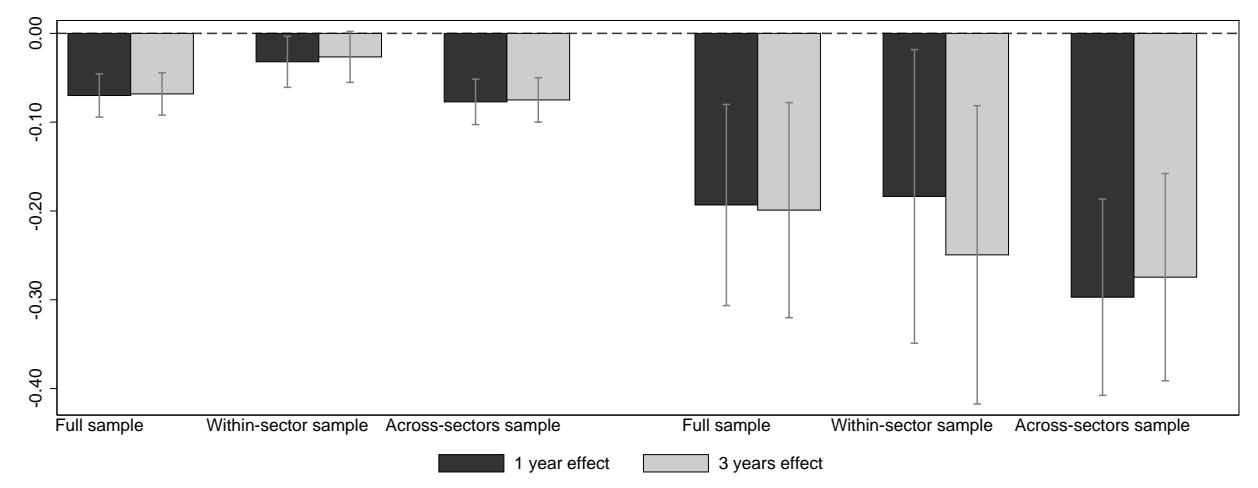

(a) Annual earnings

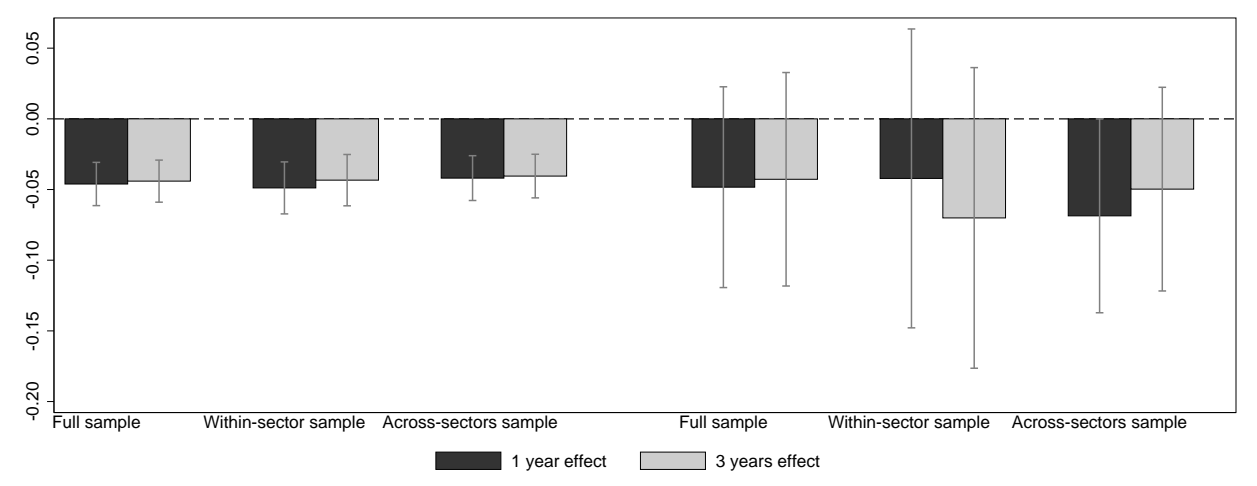

(b) Annual weeks worked

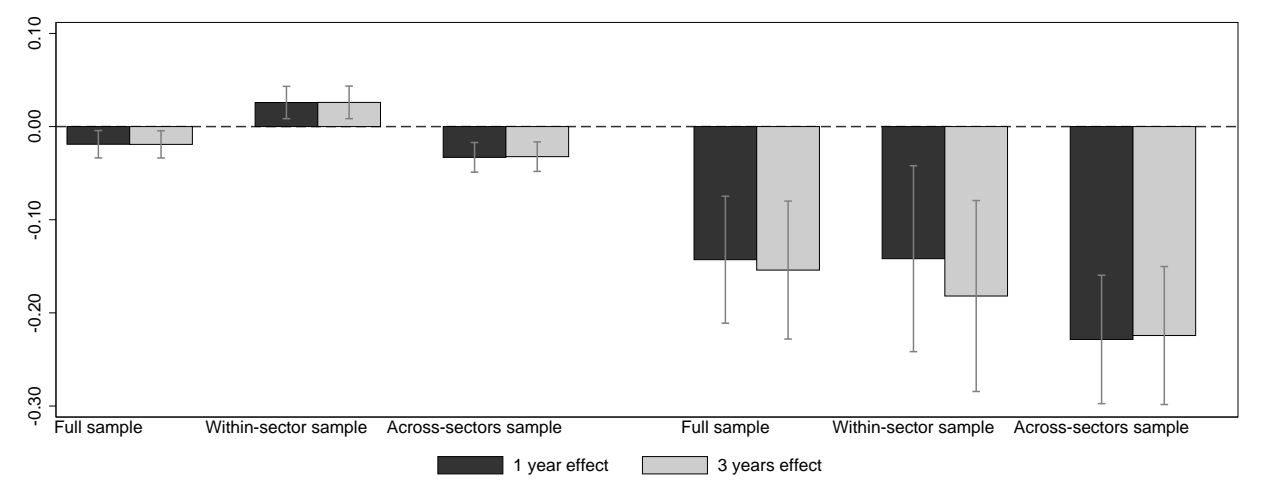

(c) Weekly wages 
Appendix E. Heterogeneous effects by age range (18-26 years old)

Figure E.1: Biagi Law, marginal effects in the 18-26 years old age group

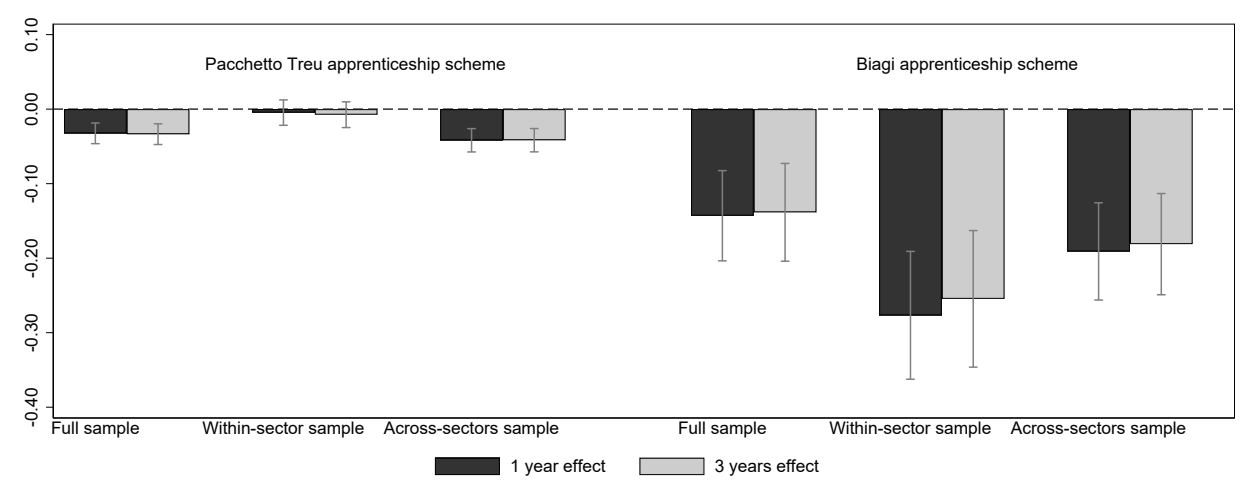

(a) Annual earnings

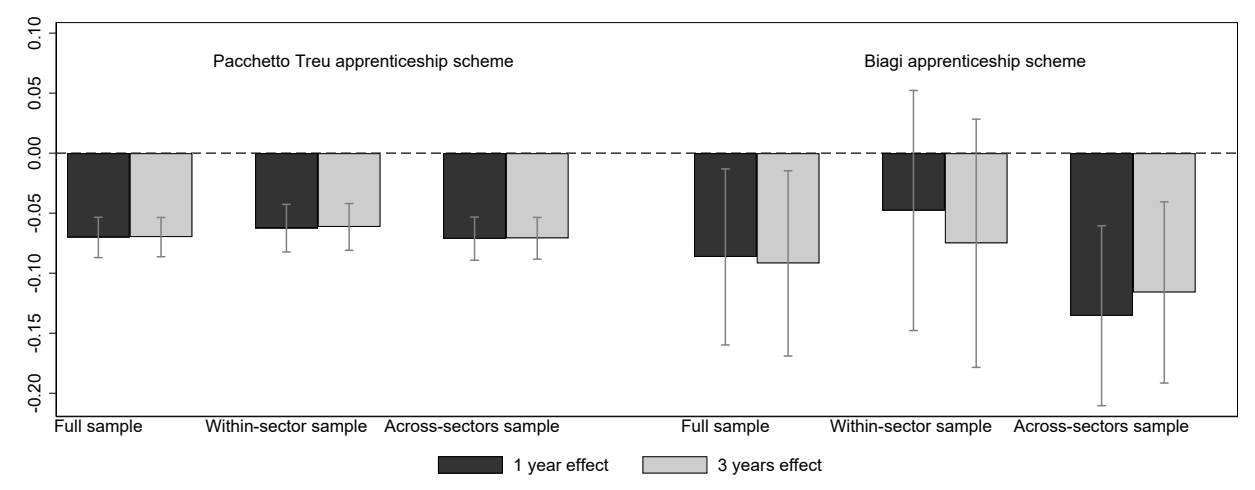

(b) Annual weeks worked

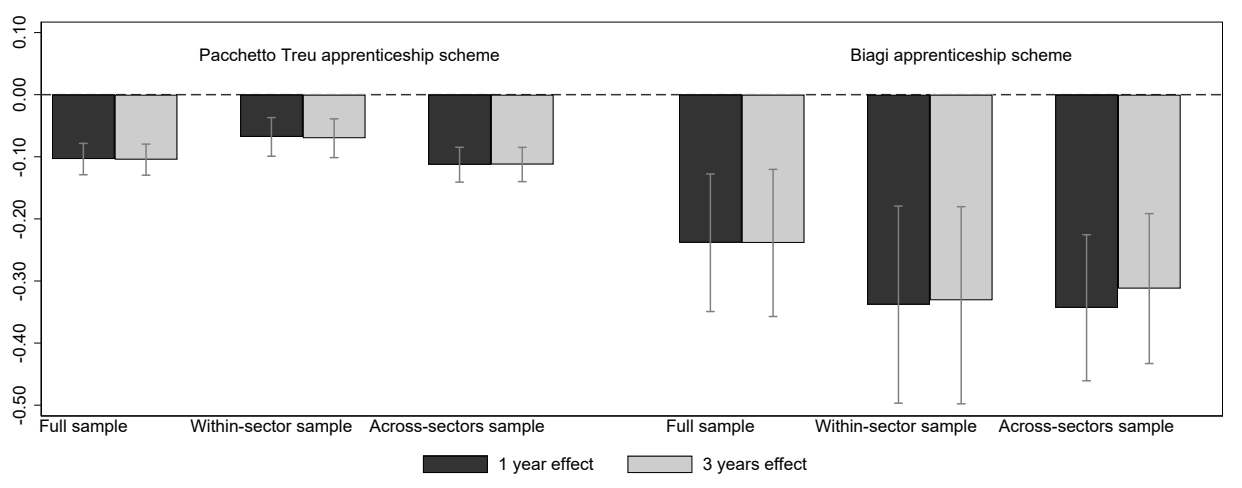

(c) Weekly wages 
Acemoglu, D., Pischke, J., 1998. Why do firms train? Theory and evidence. The Quarterly Journal of Economics 113 (1), 79-119.

Acemoglu, D., Pischke, J., 1999a. Beyond Becker: Training in imperfect labour markets. The Economic Journal 109 (453), 112-142.

Acemoglu, D., Pischke, J., 1999b. The structure of wages and investment in general training. Journal of Political Economy 107 (3), 539-572.

Adda, J., Triggari, A., 2016. Labor market inequalities across italian demographic groups: A focus on the youth and the long-term unemployed. Policy Brief 1, IGIER, Universita Bocconi, Milano.

Albanese, A., Cappellari, L., Leonardi, M., 2017. The effects of youth labor market reforms: Evidence from italian apprenticeships. CESifo Working Paper Series 6481, CESifo Group Munich, Munich.

Angrist, J. D., 2001. Estimation of limited dependent variable models with dummy endogenous regressors: simple strategies for empirical practice. Journal of Business \& Economic Statistics 19 (1), 2-28.

Bardazzi, R., Duranti, S., 2016. Atypical work: A threat to labour productivity growth? some evidence from Italy. International Review of Applied Economics 30 (5), 620-643.

Bassanini, A., Booth, A., Brunello, G., De Paola, M., Leuven, E., 2006. Education and Training in Europe. Oxford University Press, Oxford, UK, Ch. Workplace Training in Europe.

Bertola, G., Garibaldi, P., 2006. Structural Unemployment in Western Europe: Reasons and Remedies. MIT Press, Cambridge Mass., Ch. The structure and history of Italian unemployment, pp. 293-315.

Bosco, M. G., Valeriani, E., Nov 2018. The road to permanent work in Italy: "It's getting dark, too dark to see". Italian Economic Journal 4 (3), 385-419.

Bratti, M., Conti, M., Sulis, G., 2018. Employment protection, temporary contracts and firm-provided training: Evidence from italy. Discussion Paper 11339, IZA Institute of Labor Economics.

Cappellari, L., Dell'Aringa, C., Leonardi, M., 2012. Temporary employment, job flows and productivity: A tale of two reforms. The Economic Journal 122 (562), F188-F215.

Choudhry, T. M., Marelli, E., Signorelli, M., 2012. Youth unemployment rate and impact of financial crises. International Journal of Manpower 33 (1), 76-95.

d'Agostino, G., Pieroni, L., Scarlato, M., 2018. Evaluating the effects of labour market reforms on job flows: The italian case. Economic Modelling 68, 178-189.

Devicienti, F., Naticchioni, P., Ricci, A., 2018. Temporary employment, demand volatility, and unions: Firm-level evidence. ILR Review 71 (1), 174-207.

Dustmann, C., Schönberg, U., 2012. What makes firm-based vocational training schemes successful? The role of commitment. American Economic Journal: Applied Economics 4 (2), 36-61.

Eichhorst, W., Rodríguez-Planas, N., Schmidl, R., Zimmermann, K. F., 2015. A road map to vocational education and training in industrialized countries. ILR Review 68 (2), 314-337.

European Commission, 2017. European alliance for apprenticeships: Good for youth, good for business. Tech. rep., Directorate-General for Employment, Social Affairs and Inclusion, Brussels.

Felli, L., Harris, C., 1996. Learning, wage dynamics, and firm-specific human capital. Journal of Political Economy 104 (4), 838-868.

Fersterer, J., Pischke, J.-S., Winter-Ebmer, R., 2008. Returns to apprenticeship training in Austria: Evidence from failed firms. The Scandinavian Journal of Economics 110 (4), 733-753.

Fitzenberger, B., Licklederer, S., Zwiener, H., 2015. Mobility across firms and occupations among graduates from apprenticeship. Labour Economics 34, 138-151. 
Göggel, K., Zwick, T., 2012. Heterogeneous wage effects of apprenticeship training. The Scandinavian Journal of Economics 114 (3), 756-779.

Hart, R. A., Ma, Y., 2010. Wage-hours contracts, overtime working and premium pay. Labour Economics $17(1), 170-179$.

ISFOL, 2010. Apprendistato: Un sistema plurale. X rapporto di monitoraggio. I libri del Fondo sociale europeo 141, ISFOL, Rome.

Korpi, T., Mertens, A., 2003. Training systems and labor mobility: A comparison between Germany and Sweden. The Scandinavian Journal of Economics 105 (4), 597-617.

Leuven, E., 2005. The economics of private sector training: A survey of the literature. Journal of economic surveys 19 (1), 91-111.

Malcomson, J. M., Maw, J. W., McCormick, B., 2003. General training by firms, apprentice contracts, and public policy. European Economic Review 47 (2), 197 - 227.

McIntosh, S., Morris, D., 2018. Labour market outcomes of older versus younger apprentices: A comparison of earnings differentials. CVER Research Paper 16, LSE, London.

Mohrenweiser, J., Zwick, T., 2009. Why do firms train apprentices? The net cost puzzle reconsidered. Labour Economics 16 (6), 631-637.

OECD, 2018. Employment Outlook 2018. Tech. rep., OECD, Paris.

Pastore, F., 2017. Getting it right: Youth employment policy within the EU. In: CESifo Forum. Vol. 18. München: Ifo Institut-Leibniz-Institut für Wirtschaftsforschung an der Universität München, pp. 26-33.

Pencavel, J., 2016. Recovery from work and the productivity of working hours. Economica 83 (332), 545-563.

Picchio, M., Staffolani, S., 2013. Does apprenticeship improve job opportunities? A regression discontinuity approach. Empirical Economics, 1-38.

Rendall, M., Weiss, F. J., 2016. Employment polarization and the role of the apprenticeship system. European Economic Review 82, 166-186.

Ryan, P., 2001. The school-to-work transition: A cross-national perspective. Journal of Economic Literature 39 (1), 34-92.

Ryan, P., Backes-Gellner, U., Teuber, S., Wagner, K., 2013. Apprentice pay in Britain, Germany and Switzerland: Institutions, market forces and market power. European Journal of Industrial Relations 19 (3), 201-220.

Steedman, H., 2012. Overview of apprenticeship systems and issues. Ilo contribution to the G20 task force on employment, ILO, Geneva.

Tiraboschi, M., 2012. Young workers in recessionary times: A caveat (to continental europe) to reconstruct its labour law? E-Journal of International and Comparative Labour Studies 1 (1-2).

Vidal, M., Tigges, L. M., 2009. Temporary employment and strategic staffing in the manufacturing sector. Industrial Relations: A Journal of Economy and Society 48 (1), 55-72.

von Wachter, T., Bender, S., 2006. In the right place at the wrong time: The role of firms and luck in young workers' careers. The American Economic Review 96 (5), 1679-1705.

Wasmer, E., 2006. General versus specific skills in labor markets with search frictions and firing costs. The American Economic Review 96 (3), 811-831.

Wooldridge, J. M., 2010. Econometric analysis of cross section and panel data. MIT Press, Cambridge Mass. 